
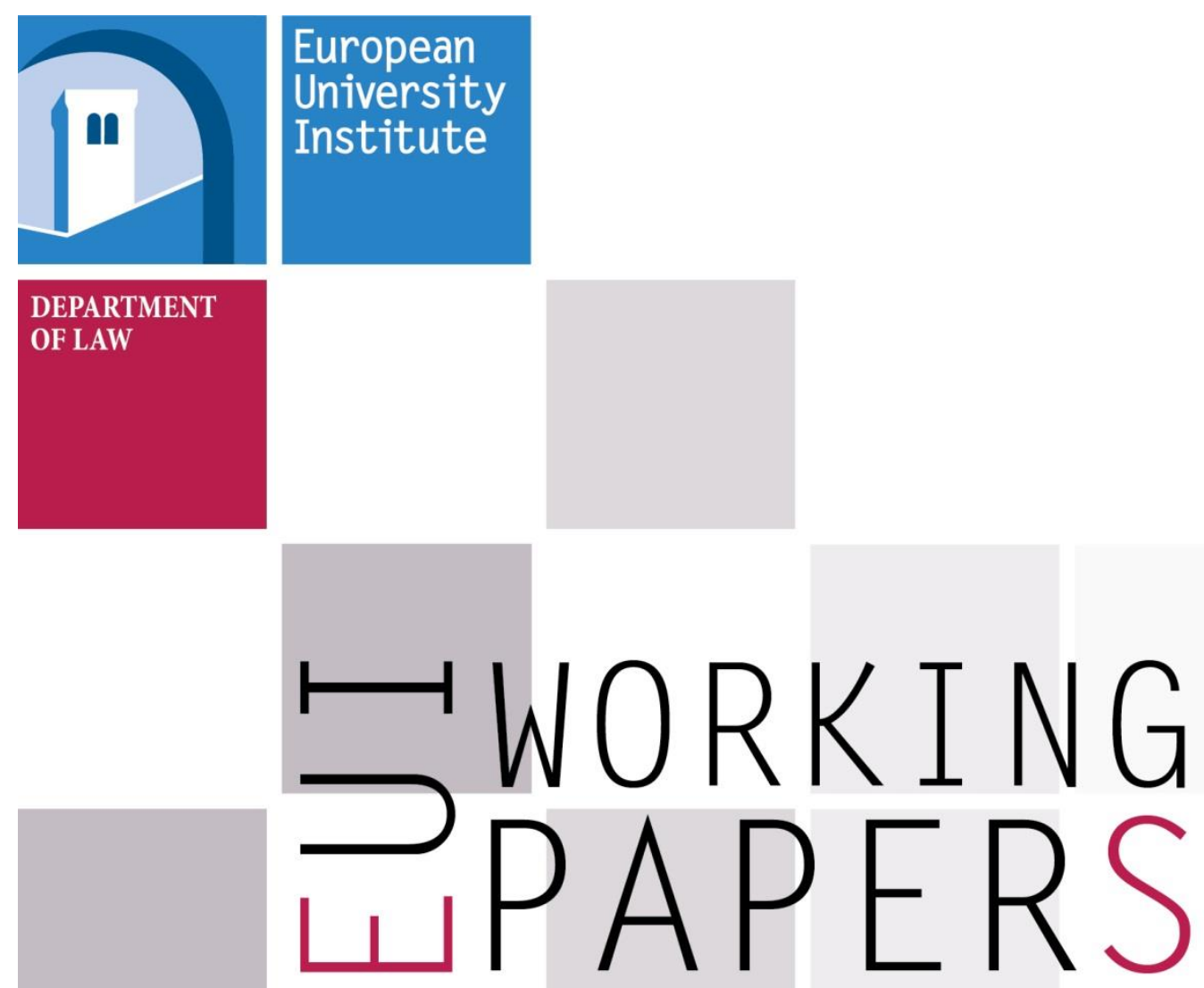

LAW 2019/05

Department of Law

Illiberalism in East-Central Europe

Gábor Halmai 

European University Institute Department of Law

\section{ILLIBERALISM IN EAST-CENTRAL EUROPE}

Gábor Halmai

EUI Working Paper LAW 2019/05 
This text may be downloaded for personal research purposes only. Any additional reproduction for other purposes, whether in hard copy or electronically, requires the consent of the author. If cited or quoted, reference should be made to the full name of the author, the title, the working paper or other series, the year, and the publisher.

ISSN 1725-6739

(C) Gábor Halmai, 2019

Printed in Italy

European University Institute

Badia Fiesolana

I-50014 San Domenico di Fiesole (FI)

Italy

www.eui.eu

cadmus.eui.eu 


\begin{abstract}
In the paper I try to answer the question, whether there is a genuine constitutional theory of 'illiberal constitutionalism,' recently advocated in some East-Central European member states of the European Union, especially in Hungary and Poland. As I demonstrate, court ideologists of populist autocrats use Carl Schmitt's concept of political sovereignty and collective identity of the people, or misuse Max Weber's leader democracy or Richard Bellamy's or others' political constitutionalism ideas to legitimize authoritarian aims. I argue that the constitutional concept, which rejects liberalism as a constitutive precondition of democracy, cannot be in compliance with the traditional idea of liberal democratic constitutionalism. This concept has nothing to do with any majoritarian constitutional model based on the separation of power, or with political constitutionalism, or any kind of weak judicial review, and it misuses the concept of constitutional identity.

One of the reasons of the illiberal turn has been that there was a lack of consensus about liberal democratic values at the time of the transition. In the beginning of the democratic transitions in these new democracies, preference was given to general economic effectiveness over mass civic and political engagement. According to some authors, the prospects for liberal constitutional democracy in the newly independent states of Central and Eastern Europe following the 1989-90 transition were diminished by a technocratic, judicial control of politics, which blunted the development of civic constitutionalism, civil society, and participatory democratic government as necessary counterpoints to the technocratic machinery of legal constitutionalism. But, there is nothing to suggest that an earlier and more participatory constitution-making process would have prevented the populist turn. Those proponents of participatory constitutionalism do not sufficiently take into account the rise of populism and the lack of civic interest in constitutional matters, due to poor constitutional culture. The recent success of illiberalism in the region seems to indicate that the special historical circumstances require a longer period of time the build up a liberal democratic political and constitutional culture. But the democratic backsliding is not a proof of the failure of liberal democracy altogether, as illiberal leaders and their court ideologists want people to believe.
\end{abstract}

\title{
Keywords
}

constitutionalism, East-Central Europe, illiberalism, authoritarianism, constitutional identity 
Author contact details:

Gábor Halmai

European University Institute

Law Department

Gabor.Halmai@EUI.eu 


\section{Table of contents}

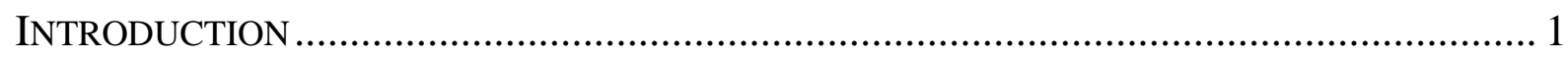

ILLIBERAL CONSTITUTIONAL THEORIES .............................................................. 2

Are There Such Things as 'Illiberal or Nonliberal Constitutionalism'? ............................... 2

Populist Autocrats Against Liberal Democracy and Constitutionalism ........................... 2

Authoritarian Populism As A Rhetoric ................................................................... 7

Is There Such A Thing As Authoritarian Constitutionalism?.......................................... 8

Can 'Nonliberal Constitutionalism' Be Really Constitutionalist?.................................. 11

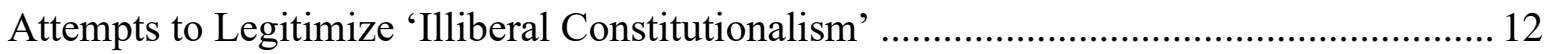

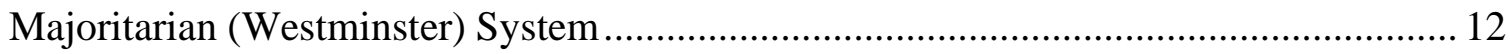

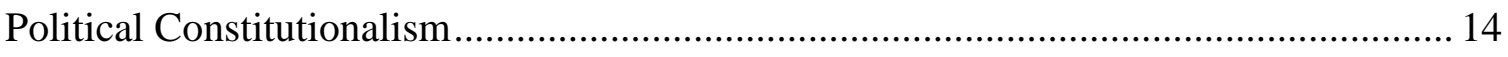

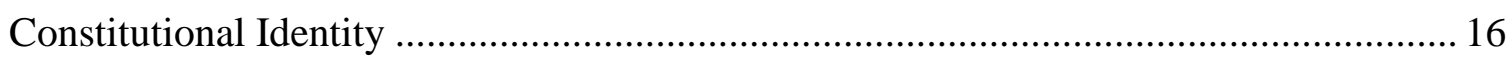

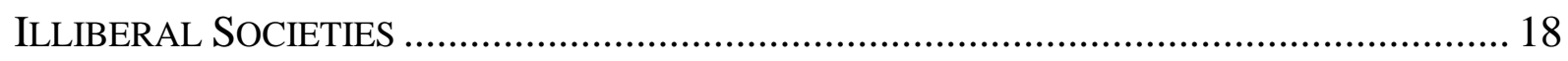

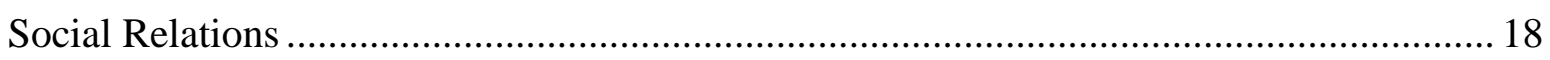

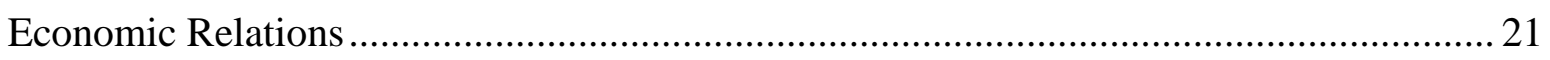

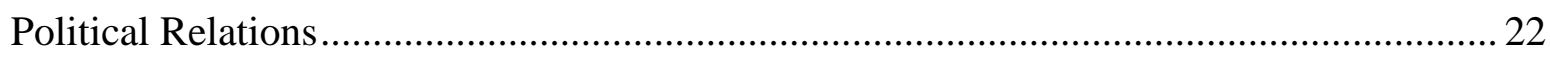

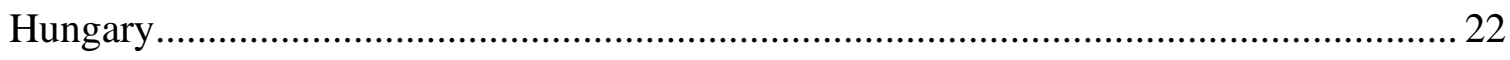

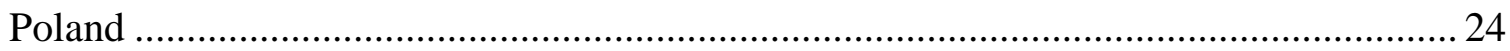

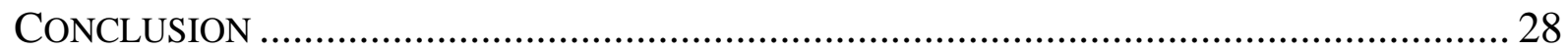





\section{Introduction*}

Illiberalism can be understand as a critical reaction to liberalism. The subject of illiberal criticism are both liberal theories and liberal societies. As Stephen Holmes argues, illiberals or antiliberals are unwilling to examine liberal theories and liberal societies separately, because they assume that liberal societies perfectly embody liberal ideas, therefore failing of liberal societies follow directly from the inadequacy of liberal principles ${ }^{1}$. This paper will discuss the current state of play of both illiberal theories and illiberal societies in East Central Europe.

Also, illiberal critics of liberalism portrays and demonizes liberalism as a single coherent phenomenon. But for instance conservative liberals have little in common with social democratic ones, or neo-liberals with classical ones ${ }^{2}$. As Ralf Dahrendorf has rightly pointed out, Friedrich von Hayek and Karl Popper may well both be seen as liberal thinkers, but their views are quite different from each other ${ }^{3}$.

While discussing illiberalism the focus of this paper will be institutional. From this perspective the main object of illiberal critique is liberal democracy, which in my view isn't merely a limit on the public power of the majority, but also presupposes rule of law, checks and balances, and guaranteed fundamental rights. This means that there is no democracy without liberalism, and there also cannot be liberal rights without democracy ${ }^{4}$. In this respect, there is no such a thing as an 'illiberal or anti-liberal democracy. ${ }^{5}$ Those who perceive democracy as liberal by definition also claim that illiberalism is inherently hostile to values associated with constitutionalism, as an institutional aspect of liberal democracy: separation of powers, constraints on the will of the majority, human rights, and protections for minorities. Therefore, the also oxymoronic 'illiberal' or 'populist' constitutionalism ${ }^{6}$ is necessarily authoritarian in character ${ }^{7}$.

\footnotetext{
* Gábor Halmai is Professor and Chair of Comparative Constitutional Law, European University Institute, Florence, Italy.

${ }^{1}$ See S. Holmes, The Anatomy of Antiliberalism, 1993. XIV.

${ }^{2}$ See J. Zielonka, Counter-Revolution, Oxford University Press, 2018. 20.

${ }^{3}$ R. Dahrendorf, Reflections on the Revolution in Europe, London: Times Books, 1990. 25-26.
}

${ }^{4}$ Cf. Jürgen Habermas, Über den internen Zusammenhang von Rechtsstaat und Demokratie, in Zum Begriff der Verfassung. Die Ordnung der Politischen, hrsg., Ulrich Preuss, Fischer, 1994. 83-94. The English version see Jürgen Habermas, Rule of Law and Democracy, European Journal of Philosophy, 1995/3. Also Juan Juan José Linz and Alfred Stepan assert that if governments, even being freely elected violate the right of individuals and minorities, their regimes are not democracies. See Juan José Linz and Alfred Stepan, 'Toward Consolidated Diemocracies, 7/2 Journal of Democracy, 1996. 14, 15. Similarly, János Kis claims that there is no such thing as nonliberal democracy, or non-democratic liberalism. See János Kis, Demokráciából autokráciába. A rendszertipológia és az átmenet dinamikája [From Democracy to Autocracy. The System-typology and the Dinamics of the Transition], Politikatudományi Szemle, 2019/1. 45-74. Those critics, which argue that liberalism as a three hundreds year old concept predates liberal democracy forget that not only democracy but also liberalism presupposes general and equal suffrage.

5 J-W. Müller, 'The Problem with 'Illiberal Democracy'.’ Project Syndicate. 21 January. 2016.

${ }^{6}$ For instance, Paul Blokker considers 'populist constitutionalism' as an alternative, conservative understanding of constitutional order, which is, among other things is a reaction to injustices resulting from liberal democratic politics, to unbalanced emphasis on formalistic liberal institutions, rights, and norms, and an aggressive institutionalisation of a liberal understanding of law in the post-1989 transformation. See Paul Blokker, 'Populist Constitutionalism,' in Carlos de la Torre (ed.), Routledge Handbook of Global Populism, Routledge, 2018; Paul Blokker, !Populism As a Constitutional Project!, 17:2 ICON, 2019. Using Isaiah Berlin's terminology on 'false populism' I argue somewhere else that this 'authoritarian populist constitutionalism' is only a rhetoric, and not a real populist appeal to the 'people.' See G. HALMAI, 'Populism, Authoritarianism and Constitutionalism', 20 German Law Journal, No. 3. 2019.

${ }^{7}$ Following Juan José Linz's classical categories authoritarianism is inbetween democratic and totalitarian political system. See Juan José Linz, Totalitarian and Authoritarian Regimes, Lynne Rienner, 2000. Writing about Franco's Spain Linz has 
Distinct from illiberal theories, the second part of the paper discusses three main relations of illiberal societies: the social, the economic and the political ones. Among other things, I want to figure out, whether the backsliding of liberalism in East-Central Europe is a proof or consequence of failure of liberal ideas.

\section{Illiberal Constitutional Theories}

\section{Are There Such Things as 'Illiberal or Nonliberal Constitutionalism'?}

\section{Populist Autocrats Against Liberal Democracy and Constitutionalism}

In a speech delivered on July 26, 2014, before an ethnic Hungarian audience in the neighboring Romania, Prime Minister Viktor Orbán proclaimed his intention to turn Hungary into a state that 'will undertake the odium of expressing that in character it is not of liberal nature.' Citing as models he added:

We have abandoned liberal methods and principles of organizing society, as well as the liberal way to look at the world . . . . Today, the stars of international analyses are Singapore, China, India, Turkey, Russia . . . and if we think back on what we did in the last four years, and what we are going to do in the following four years, then it really can be interpreted from this angle. We are . . parting ways with Western European dogmas, making ourselves independent from them . . . If we look at civil organizations in Hungary, ... we have to deal with paid political activists here ... [T] hey would like to exercise influence . . . on Hungarian public life. It is vital, therefore, that if we would like to reorganize our nation state instead of it being a liberal state, that we should make it clear, that these are not civilians . . opposing us, but political activists attempting to promote foreign interests ... This is about the ongoing reorganization of the Hungarian state. Contrary to the liberal state organization logic of the past twenty years, this is a state organization originating in national interests ${ }^{8}$.

Four years later at the same venue Orbán again expressed his support for illiberal democracy, adding that he considers Christian democracy as illiberal as well:

There is an alternative to liberal democracy: it is called Christian democracy...Let us confidently declare that Christian democracy is not liberal. Liberal democracy is liberal, while Christian democracy is, by definition, not liberal: it is, if you like, illiberal. ${ }^{9}$

In June 2019, after Fidesz was suspended from the center-right party family, EPP has set up a special committee to examine the Fidesz party's adherence to democratic standards. One of the questions the members of the committee, former Austrian Chancellor Wolfgang Schüssel, former European Council President Herman Van Rompuy and former European Parliament President Hans-Gert Pöttering addressed to Viktor Orbán has been: 'Please explain what you mean by the expression 'illiberal state'? Here is the Fidesz chairman and Hungarian Prime Minister's response:

already outlined the following four main charactersitics of authoritarianism: limited, not responsible political pluralism, without elaborate and guiding ideology, without political mobilization, and with formally ill-defined, but quite predictable limits of power. See Juan José Linz, 'An Authoritarian Regime: the Case of Spain', in Cleavages, Ideologies and Party Systems, Eric Allard and Yrjo Littunen (eds.) Helsinki, 1970. About the constitutional markers of authoritarianism as a pretence of democracy, such as the lack of procedural rights, institutional guarantees and public discourse see Gábor Attila Tóth, Constitutional Markers of Authoritarianism, Hague Journal on the Rule of Law, Published online: 10 September 2018.

${ }^{8}$ See Viktor Orbán, Speech at Băile Tuşnad (Tusnádfürdő) of 26 July 2014, Budapest Beacon, July 29, 2014, http://budapestbeacon.com/public-policy/full-text-of-viktor-orbans-speech-at-baile-tusnad-tusnadfurdo-of-26-july-2014/.

${ }^{9}$ See Prime Minister Viktor Orbán’s Speech at the 28 $8^{\text {th }}$ Bálványos Summer Open University and Student Camp, 28 July 2018. Tusnádfürdő (Băile Tuşnad). http://www.miniszterelnok.hu/prime-minister-viktor-orbans-speech-at-the-29th-balvanyossummer-open-university-and-student-camp/ 
We are Christian democrats and we are differing nowadays at least in three aspects from the liberals: The first one is the conviction that family is fundamental, and family is based on one man an one woman. We believe that this needs to be protected, which the liberals deny. Secondly, while the cultural life of every country is diverse, a Leitculture, a cultural tradition is present everywhere. In Hungary this is Christian culture. We respect other cultures, but our own has a prominent role for us, and it is our responsibility to preserve it. Liberals refuse this concept. The third aspect is that liberal democrats are everywhere pro-immigration while we are against immigration. So whether one admits it or not: Christian democrats are illiberals by definition ${ }^{10}$.

In a conversation with the French philosopher, Bernard-Henry Lévy Orbán identified liberalism with totalitarianism, and illiberalism with true democracy:

Liberalism gave rise to political correctness - that is, to a form of totalitarianism, which is the opposite of democracy. That's why I believe that illiberalism restores true freedom, true democracy. ${ }^{11}$

In July 2019 in the yearly Băile Tuşnad/Tusnádfürdö Free University Orbán admitted that 'illiberalism' carries a negative connotation, and therefore he changed the terminology calling illiberalism 'Christian liberty,' which according to him is 'a genuine model of a theory of state, a unique Christian democratic state.' He made it clear however that 'Christian liberty does not mean individual liberty, because 'individual freedoms can never encroach on the interests of the community. There is indeed a majority that must be respected, that is the foundation of democracy. ${ }^{12}$

In a speech, delivered in mid-September 2019 at the $12^{\text {th }}$ congress of the Association of Christian Intelligentsia he said that 'Christian liberty' is superior to the individual liberty - defined by John Stuart Mill in his On Liberty -, which can only be infringed upon if the exercise of one's liberty harms others. Christian liberty, by contrast, holds that we ought to treat others as we want to be treated. ${ }^{13}$ 'The teachings of 'Christian liberty' - he added - maintain that the world is divided into nations.' As opposed to liberal liberty, which is based on individual accomplishments, the followers of 'Christian liberty' acknowledge only those accomplishments that also serve the common good. While liberals are convinced that liberal democracies will eventually join together to form a world government a' la Immanuel Kant in the name of liberal internationalism, Christian liberty by contrast considers 'nations to be as free and sovereign as individuals are, and therefore they cannot be forced under the laws of global governance.'

In the system 'Christian liberty' Hungary has a special place:

We shouldn't be afraid to declare that Hungary is a city built on a hill, which, as is well known, cannot be hidden. Let's embrace this mission, let's create for ourselves and show to the world what a true, deep, and superior life can be built on the ideal of Christian liberty. Perhaps this lifeline will be the one toward which the confused, lost, and misguided Europe will stretch its hand. Perhaps they will

${ }^{10}$ The leaked letter has been published by Politico: https://www.politico.eu/article/viktor-orban-rejects-epp-concerns-rule-oflaw/

${ }^{11}$ Bernard-Henry Lévy, 'How an Anti-totalitarian Militant Discovered Ultranationalism. After 30 years, I spoke with Viktor Orbán again', The Atlantic, May 13, 2019.

12 http://www.miniszterelnok.hu/yes-to-democracy-no-to-liberalism/. As Yale law and history professor, Samuel Moyn pointed out President Trump has also begun to nudge the political culture to the same direction. He quoted Sohrab Ahmari, a conservative journalist, who approvingly explained Trump's policy as re-ordering the common good and ultimately the 'Highest Good,' that is, the Christian God - Moyn argues. See Samual Moyn, 'We'Are in An Anti-Liberal Moment. Liberals Need Better Answers,' The Washington Post, 21 June 2019.

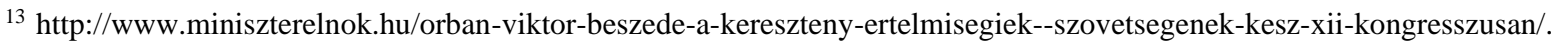
This time the webpage of the Prime Minister besides the original Hungarian text of the speech contains no English, but only a German language translation: http://www.miniszterelnok.hu/viktor-orbans-rede-auf-dem-kongress-des-verbandesder-christlichen-intellektuellen-kereszteny-ertelmisegiek-szovetsege-kesz/ 
also see the beauty of man's work serving his own good, the good of his country, and the glory of God. $^{14}$

Another new element of the speech that Orbán puts 'Christian liberty' at the center of the 'Christian democratic state', 'a new and authentic model of state and political theory,' which has been reached in the last thirty years by two big steps. The first has been the liberal democratic transition in 1989, while the second, more important one is the national or Christian regime change in 2010.

Regarding the new constitutional order, introduced by the 2011 Fundamental Law of Hungary, Orbán admitted that his party did not aim to produce a liberal constitution. He said:

In Europe the trend is for every constitution to be liberal, this is not one. Liberal constitutions are based on the freedom of the individual and subdue welfare and the interest of the community to this goal. When we created the constitution, we posed questions to the people. The first question was the following: what would you like; should the constitution regulate the rights of the individual and create other rules in accordance with this principle or should it create a balance between the rights and duties of the individual. According to my recollection more than $80 \%$ of the people responded by saying that they wanted to live in a world, where freedom existed, but where welfare and the interest of the community could not be neglected and that these need to be balanced in the constitution. I received an order and mandate for this. For this reason the Hungarian constitution is a constitution of balance, and not a side-leaning constitution, which is the fashion in Europe, as there are plenty of problems there ${ }^{15}$.

Orbán also refused separation of powers, checks and balances as concepts alien to his illiberal constitutional system:

Checks and balances is a U.S. invention that for some reason of intellectual mediocrity Europe decided to adopt and use in European politics ${ }^{16}$.

The ideological foundation of Orbán's illiberalism can be found in the works of his two court ideologues, the sociologist and former liberal MP, Gyula Tellér and András Lánczi, a political scientist. It is easy to prove that Orbán in his 2014 speech on 'illiberal democracy' recited a study of Tellér published earlier on that year, what Orbán assigned as compulsory reading for all his ministers. ${ }^{17}$ Tellér claims that the 'system of regime-change' has failed because the liberal constitution did not commit the government to protect national interests, therefore the new 'national system' has to strengthen national sovereignty, and with it the freedom of degree of government activity. This, Tellér argues is necessary against the moral command of the liberal rule of law regime, according to which 'everything is allowed, what does not harm others' liberty'.

Lánczi's antiliberal concept can be found in his book Political Realism and Wisdom, which was published in English in 2015, as well as in an article published in 2018, after Fidesz' third consecutive

\footnotetext{
${ }^{14}$ As Éva S. Balogh points out this passage is taken from the Gospel of Matthew, (5:13-15), without identifying it. See Éva S. Balogh, Orbán, the New Jesus Delivers His Sermon on the Mount, Hungarian Spectrum, 15 September 2019. https://hungarianspectrum.org/2019/09/15/orban-the-new-jesus-delivers-his-sermon-on-the-mount/

15 See A Tavares jelentés egy baloldali akció (The Tavares report is a leftist action), Interview with PM Viktor Orbán in the Hungarian Public Radio, Kossuth Rádió, July 5, 2013.

${ }^{16}$ Interview with Bloomberg News, December 14, 2014. Similarly, Tünde Handó, head of the National Judicial Office, a close ally of Orbán said "The rule of law over the State, like, for example, in the United States, is not the right way". https://nepszava.hu/3029940_hando-nem-kell-a-birosagoknak-szembehelyezkedniuk-az-allammal

${ }^{17}$ See Gyula Tellér, Született-e Orbán-rendszer 2010 és 2014 között? [Was an Orbán System Born between 2010 and 2014?], NAGYVILÁG, March 2014.
} 
electoral victory ${ }^{18}$. Lánczi's critique is an outright rejection of liberalism as a utopian ideology, which is - similar to Communism - incompatible with democracy.

Similarly to Orbán, the that time Prime Minister Beata Szydło (with Kaczyński, ruling from behind the scenes as he holds no official post), have described the actions of the PiS government dismantling the independence of the Constitutional Tribunal and the ordinary courts as a blitz to install an illiberal state. In mid-September 2016 at a conference in the Polish town of Krynica, Orbán and Kaczyński proclaimed a 'cultural counter-revolution' aimed at turning the European Union into an illiberal project. A week later at the Bratislava EU summit, the prime ministers of the Visegrád 4 countries demanded a structural change of the EU in favour of the nation states. ${ }^{19}$ Witold Waszczykowski, Poland's minister of foreign affairs expressing his own and his governing PiS party's antiliberalism went as far as to mock liberalism as 'a world made up of cyclists and vegetarians, who only use renewable energy and fight all form of religion' 20 .

Ryszard Legutko, the main ideologue of PiS, similarly to his Hungarian counterpart, Lánczi, also likens liberal democracy with Communism both being fuelled by the ideas of modernization and progress ${ }^{21}$. Both Lánczi and Legutko assert together with other antiliberals with one voice that liberalism and Communism, or for that matter its ideology, Marxism are secretly allied and share a common ancestry that they are two offshoots of an Enlightenment tradition ${ }^{22}$. Legutko also accuses liberalism's tendency to root out all forms of inequality, and that human right - as legal norms that promote equality become 'arbitrary claims, ideologically motivated, made by various political groups in blatant disregard of the common good. 23

This critique of liberalism goes back to the concept of Volksgemeinschaft (national community), or völkisches Recht, one of the core principles of National Socialist law, which can be characterized negatively by rejection of the individualistic, normative concept of the people (Volk) as the sum of nationals of the State, as presented in the 1918 Weimar Constitution ${ }^{24}$. Volksgemeinschaft together with the Führerprinzip, the other main principle of National Socialist Weltanschauung aim to overcome individualism, hence it means strong anti-liberalism. Due the Carl Schmitt's well-known flirts with National Socialism it isn't surprising that the critical stance of the new illiberals towards liberal

${ }^{18}$ See András Lánczi, The Renewed Social Contract-Hungary's Elections, 2018, IX Hungarian Rev., May 2018, at http://www.hungarianreview.com/article/20180525_the_renewed_social_contract_hungary_s_elections_2018. A detailed analysis of Lánczi's arguments see See Kim L. Scheppele, The Opportunism of Populists and the Defense of Constitutional Liberalism, 20 GERMAN LAW JOURNAL, 3, 2019.

${ }^{19}$ Slawomir Sierakowski even speaks about an 'illiberal international'. See S. Sierakowski, 'The Polish Threat to Europe', Project Syndicate, January 19, 2016.

${ }^{20}$ https://www.bild.de/politik/ausland/polen/hat-die-regierung-einen-vogel-44003034.bild.html

${ }^{21}$ See Ryszard Legutko, The Demon in Democracy: Totalitarian Temptations in Free Societies, 2016. 2-9.

${ }^{22}$ This anti-liberal political theory is present outside East-Central Europe as well. For instance Patrick Deneen's book, Why Liberalism Failed (2018) is directed at the left in the US targeting both contemporary progressivism and 'classical liberalism' of conservatives. The Israeli political theorist Yoram Hazony, whose book The Virtue of Nationalism (2018) also crtiticizes those conservatives who defend liberal democracy. As Marc Plattner convinsingly argues, the common goal of all these thinkers is to conflate liberal democracy with contemporary progressivism and thus to suggest that conservatives should have no interest in supporting or defending liberal democracy. See M. Plattner, 'Illiberal Democary and the Struggle ont he Right', Journal of Democracy, Volume 30, Number 1, January 2019. 16-17.

${ }^{23}$ Legutko, ibid n. 21, 135. In a recent article, Paul Blokker characterises both Legutko and Lánczi as a conservative intellectual who has provided ideas for the conservative populist project, and important contribution to rethinking/re-imagining constitutional democracy in the contemporary European context. See Paul Blokker, 'Populist Counter-Constitutionalism, Conservatism, and Legal Fundamentalism, European Constitutional Law, forthcoming.

${ }^{24}$ About the role of Volksgemeinschaft in National Socialist law see Oliver Lepsius? 'The Problem of Perceptions of National Socialist Law or: Was There A Constitutional Theory of National Socialism?', in Christian Joerges and Navraj Singh Ghaleigh (eds.), Draker Legacies of Law in Europe. The Shadow of National Socialism and Fascism over Europe and its Legal Traditions, Hart Publishing, 2003. 19-41. 
constitutionalism is also related to a Schmittian understanding of the constitution, and to his critique of liberal constitutionalism and its conception of the rule of law ${ }^{25}$. The constitution in Schmitt's view is an expression of 'the substantial homogeneity of the identity and the will of the people', and guarantee of the state's existence, and ultimately any constitutional arrangement is grounded in, or originates from, an arbitrary act of political power. The absolute authority of the political will of the people overrides all constitutional requirements, which according to Schmitt are signs of depoliticization tendencies caused by liberal democracies. This is the reason that he elaborated The concept of the Political ${ }^{26}$ (Das Politisches) based on the distinction between friend and enemy, which is precisely the opposite of liberal neutrality ${ }^{27}$.

In other words, in Schmitt's view the basis of the constitution is 'a political decision concerning the type and form of its own being', made by the people as a 'political unity', based on their own free will. This political will 'remains alongside and above the constitution. ${ }^{28}$ Schmitt also portrays the people as an existential reality as opposed to the mere liberal representation of voters in parliament, holding therefore that Mussolini was a genuine incarnation of democracy. Schmitt goes so far as to claim the incompatibility of liberalism and democracy, and argues that plebiscitary democracy based on the homogeneity of the nation is the only true form of democracy. But Schmitt is talking about these intermittent plebiscites as a tool to tap the resource of consent by the governed within a 'qualitative' and strong totalitarian state, the authority of which rests on the military and the bureaucracy, and which cannot accept the existence of political opposition ${ }^{29}$. In other words the strong state cannot be liberal ${ }^{30}$.

As Mattias Kumm argues, Carl Schmitt's interpretation of democracy, inspired by Rousseau, and used by authoritarian populist nationalists, like Viktor Orbán as 'illiberal democracy', becomes an anticonstitutional topos. ${ }^{31}$ The Hungarian political scientist, András Körösényi, implementing the Weberian concept calls the Orbán regime as 'plebiscitary leader democracy', where the activity of the leader (or Führer? - G.H.) is posteriorly approved by the people, but since this approval can be withdrawn this is

${ }^{25}$ As Heiner Bielefeld demostrates Carl Schmitt systematically undersmines the liberal principle of the rule of law. See Heiner Bielefeld, 'Deconstruction of the Rule of Law. Carl Schmitt's Philosophy of the Policial', 82 Archiv für Rechts- und Sozialphilosophy, 1996. 379-396.

${ }^{26}$ Carl Schmitt, The Concept of the Political, 2007.

${ }^{27}$ See Heiner Bielefeld, 'Carl Schmitt's Critique of Liberalism: Systematic Reconstitruction and Countercriticism', Canadian Journal of Law and Jurisprudence, Vol. X, No. 1. (January 1997). 67.

${ }^{28}$ See Carl Schmitt, Constitutional Theory, 2008. 125-126. This idea is also shared by a part of the French constitutional doctrine, influenced by Rousseau's general will. This is the reason that the representatives of this doctrine hold that during a constitutional transition a referendum is sufficient to legitimate a new constitution. See the French Constitutional Council's approval of De Gaulle's 1962 amendment to the 1958 Constitution, ignoring the Constitution's amendment provisions.

${ }^{29}$ See Carl Schmitt, Legalität and Legitimität, note 51, at 93-94. Quoted by Alexander Somek, Authoritarian Constitutionalism: Austrian Constitutional Doctrine 1933-1938 and Its Legacy, in Darker Legacies of Law in Europe: The Shadow of National Socialism and Fascism Over Europe and Its legal Traditions (Christian Joerges and Navraj Singh Ghaleigh eds., 2003), 375 .

${ }^{30}$ About the revival of Carl Schmitt in the Hungarian political and constitutional theory see Attila Antal, 'The Rebirth of the Political - A Schmittian Moment in Hungary,' Transcript of the lecture given at the Constitutional systems in Middle Europe; The cycle of meetings about political ideas of Tadeusz Mazowiecki organized by Polska Fundacja im. Roberta Schumanaon 6th November 2017, Warsaw. https://www.academia.edu/35061692/The_Rebirth_of_the_Political__A_Schmittian_Moment_in_Hungary_Transcript_of_Lecture?email_work_card=thumbnail. Also Zoltán Balázs, 'Political Theory in Hungary After the Regime Change', 7 International Political Anthropology, 2014. no. 1, 5-26. On Schmitt's influence of the Polish constitutional discourse see Dawid Bunikowski, 'The crisis in Poland, Schmittian Questions, and Kaczyński's Political and Legal Philosophy, https://www.academia.edu/31450497/The_crisis_in_Poland_ and_Schmittian_questions_in_the_rule_of_law_debate

${ }^{31}$ Mattias Kumm, Demokratie als verfassungsfeindlicher Topos, Verfassungsblog, Sept. 6, 2017. 
still a democratic system ${ }^{32}$. In contrast, Wojciech Sadurski using Guillermon O'Donnell's 'delegative democracy' concept characterises the Polish system after 2015 as 'plebiscitary autocracy', in which the electorate approves of governmental disregard of the constitution ${ }^{33}$. In Hungary even the electoral approval is manipulated, hence the formal democratic character of the regime can be also be questioned. This lead Larry Diamond to call the Hungarian sytem as 'pseudo-democracy' ${ }^{34}$.

\section{Authoritarian Populism As A Rhetoric}

The illiberal regimes in Central and Eastern Europe manifest themselves populist, using antirepresentation and pro-direct democracy arguments. But in reality this is only a rhetoric, which does not necessarily correspond with these populists' practice. For instance, Viktor Orbán's Fidesz party tried to undermine the legitimacy of representation after losing the 2002 parliamentary elections ${ }^{35}$. He refused to concede defeat, declaring that 'the nation cannot be in opposition, only the government can be in opposition against its own people'. After the 2010 electoral victory, he claimed that through the 'revolution at the voting booths', the majority has delegated its power to the government representing it. This means that the populist government tried to interpret the result of the elections as the will of the people, viewed as a homogenous unit. Also, the Orbán government, which after in 2010 overthrowing its predecessor as a result of a popular referendum made it more difficult to initiate a valid referendum for its own opposition. While the previous law required only 25 percent of the voters to cast a vote, the new law requires at least 50 percent of those eligible to vote to take part, otherwise the referendum is invalid $^{36}$. The ambivalence of authoritarian populists towards representation and referenda in government and in opposition applies to their attitude regarding established institutions. While they readily attack the 'establishment', while in opposition, they very much protect their own governmental institutions. The situation is different with transnational institutions, like the EU, which are also attacked

${ }^{32}$ See András Körösényi, Weber és az Orbán-rezsim: plebiszciter vezéremokrácia Magyarországon [Weber and the Orbánregime: Plebisciter Leader Democracy in Hungary], Politikatudományi Szemle, 2017/4. 7-28. In a more recent interview however, Körösényi admitted that the for the witdrawal of approval currently a miracle is needed. See Csak a csoda segít [Only the Miracle Helps], hvg, 20 June 2019.

${ }^{33}$ See Wojciech Sadurski, Poland's Constitutional Breakdown, Oxford Univesity Press, 2019. 242-243. Similarly, Juan José Linz to avoid confusion proposes the addition of adjectives to 'authoritarianism' rather than to 'democracy' for such regimes: for example 'electoral authoritarianism.' See Juan José Linz, Totalitarian and Authoritarian Regimes, Lynne Rienner, 2000. 34. Also, Larry Diamond refers to 'electoral authortarianism' in hybrid regimes. See Larry Diamond, 'Thinking About Hybrid Regimes’ 13/2 Journal of Democracy, 2002. 21, 24.

34 „The test of a democracy is not whether the economy is growing, employment is rising, or more couples are marrying, but whether people can choose and replace their leaders in free and fair elections. This is the test that Hungary's political system now fails. When Viktor Orbán and his Fidesz party returned to power in 2010 with a parliamentary supermajority, they set about destroying the constitutional pillars of liberal democracy ... By the 2014 elections, Orbán had rigged the system. Yes, multiparty elections continued, but his systematic degradation of constitutional checks and balances so tilted the playing field that he was able to renew his two-thirds majority in parliament with less than a majority of the popular vote (and did so again in 2018) ... Orbán has transformed Hungary into not an illiberal democracy but a pseudo-democracy". See Larry Diamond, 'How Democratic Is Hungary?', Foreign Affairs, September/October 2019. Similarly, Steven Levitsky and Lucan Way recently argued: "Clearly, Hungary is not a democracy. But understanding why requires a nuanced understanding of the line between democracy and autocracy ... Orbán's Hungary is a prime example of a competitive autocracy with an uneven playing field'. Steven Levitsky and Lucan Way, 'How autocrats can rig the game and damage democracy', The Washington Post, 4 January 2019. See also András Bozóki \& Dániel Hegedűs, 'An externally constrained hybrid regime: Hungary in the European Union" (2018) Democratization 1173.

${ }^{35}$ About the use of populist rhetoric by Viktor Orbán and his government see a more detailed description in my article 'Populism, Authoritarianism and Constitutionalism', 20 German Law Journal, 3 (2019), 296-313.

${ }^{36}$ It is the irony of fate that due to these more stringent conditions, the only referendum that the Orbán government initiated one against the EU's migration policy - failed. On 2 October 2016, Hungarian voters went to the polls to answer one referendum question: "Do you want to allow the European Union to mandate the relocation of non-Hungarian citizens to Hungary without the approval of the National Assembly?". Although $92 \%$ of those who casted votes and 98 of all the valid votes agreed with the government, answering 'no' ( $6 \%$ were spoiled ballots), the referendum was invalid because the turnout was only around 40 percent, instead of the required 50 percent. 
by these autocratic populist governments as threats to their countries' sovereignty ${ }^{37}$. A good example is again the Hungarian Parliament's reaction to the European Parliament's critical report from July 2013 on the constitutional situation in Hungary. The Hungarian parliamentary resolution on equal treatment reads: 'We, Hungarians, do not want a Europe any longer where freedom is limited and not widened. We do not want a Europe any longer where the Greater abuses his power, where national sovereignty is violated and where the Smaller has to respect the Greater. We have had enough of dictatorship after 40 years behind the iron curtain.' These words very much reflect the Orbán government's view of 'national freedom', the liberty of the state (or the nation) to determine its own laws: 'This is why we are writing our own constitution...And we don't want any unconsolidated help from strangers who are keen to guide us...Hungary must turn on its own axis'. ${ }^{38}$

Orbán repeated the same populist, nationalist mantra at the plenary debate of the European Parliament on 11 September 2018, when defying the Sargentini report, on the basis of which the Parliament launched Article 7 TEU proceedings against Hungary: '...you are not about to denounce a government, but a country and a people. You will denounce the Hungary, which has been a member of the family of Europe's Christian peoples for a thousand years; the Hungary which has contributed to the history of our great continent of Europe with its work and, when needed, with its blood. You will denounce the Hungary which rose and took up arms against the world's largest army, against the Soviets, which made the highest sacrifice for freedom and democracy, and, when it was needed, opened its borders to its East German brothers and sisters in distress. Hungary has fought for its freedom and democracy. I stand here now and I see that Hungary is being arraigned by people who inherited democracy, not needing to assume any personal risk for the pursuit of freedom. [...] the report before you is an affront to the honor of Hungary and the Hungarian people. Hungary's decisions are made by the voters in parliamentary elections. What you are claiming is no less than saying that the Hungarian people are not sufficiently capable of being trusted to judge what is in their own interests. You think that you know the needs of the Hungarian people better than the Hungarian people themselves. ${ }^{39}$

Hence, I claim that autocrats' populism is 'false' ${ }^{40}$ and they only use populist rhetoric, but their decisive characteristics is authoritarianism. What makes them distinct from non-populist autocrats are the democratic elections through which they come to power, even though being in government they often change the electoral law to keep their power.

\section{Is There Such A Thing As Authoritarian Constitutionalism?}

Constitutionalism is often defined as 'limited government.' For instance Giovanni Sartori defines constitutionalism as 'a fundamental law, or a fundamental set of principles, and a correlative institutional arrangement, which would restrict arbitrary power and ensure 'limited government" ${ }^{41}$. Also, András

\footnotetext{
${ }^{37}$ Andrea Pin in the parallel special issue argues that supranational courts are partially also responsible for the rise of populism by judicialization of political choices and replacing national debates and rules. In my view this critique does not apply in the case of Member States of the EU, such as Hungary and Poland, where the democratic process is not operating satisfactorily, and the political institutions of the EU seem to be unable or unwilling to act. Here the CJEU or the ECtHR for that matters, despite their otherwise problematic de-politicized language, can be the last resort to enforce compliance with European values. See Andrea Pin, The Transnational Drivers of Populist Backlash in Europe: The Role of the Courts, XX GER L.J. XX (2019).

${ }^{38}$ The English-language translation of excerpts from Orbán's speech was made available by Hungarian officials, see e.g. Financial Times: Brussels Blog, 16 March 2012.

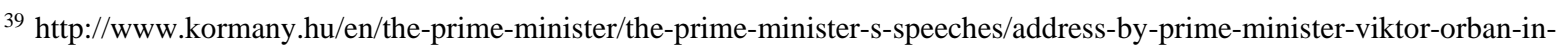
the-debate-on-the-so-called-sargentini-report

40 The term 'false' populism was used by Isaiah Berlin defining "the employment of populist ideas for undemocratic ends". See To Define Populism, The Isaiah Berlin Virtual Library, Isaiah Berlin 1968, The Isaiah Berlin Literary Trust 2013. Posted 14 October 2013. 6. http://berlin.wolf.ox.ac.uk/lists/bibliography/bib111bLSE.pdf. 10.

${ }^{41}$ See Giovanni Sartori, Constitutionalism: A Preliminary Discussion, 56 The American Political Science Review, 1962. 855.
} 
Sajó and Renáta Uitz describe constitutionalism as a liberal political philosophy that is concerned with limiting government ${ }^{42}$. The main aim of limiting government is to guarantee individual rights. In other words, modern constitutionalism is by definition liberal ${ }^{43}$. This does not mean, however, that constitutions cannot be illiberal or authoritarian. Therefore, it is legitimate to talk about constitutions in authoritarian regimes, as Tom Ginsburg and Alberto Simpler do in their book, ${ }^{44}$ but I do not agree with the use of the term 'authoritarian constitutionalism' ${ }^{45}$ or 'constitutional authoritarianism' ${ }^{46}$

Mark Tushnet for instance tries to generally pluralize the normative understanding of non-liberal constitutionalism, differentiating between an absolutist, a mere rule-of-law, and an authoritarian form of constitutionalism, Singapore being the main example of the latter ${ }^{47}$. Tushnet defines authoritarian constitutionalism as an intermediate normative model between liberal constitutionalism and authoritarianism ${ }^{48}$ that has moderately strong normative commitments to constitutionalism in nations with specific social and political problems, such as a high degree of persistent ethnic conflict. ${ }^{49}$ In other words, he refers to a distinct type of regime, wherein there are faulty practices and a constitution with an authoritarian content.

In contrast to Tushnet's understanding of authoritarian constitutionalism, which can also be considered as an empirical work about hybrid regimes, Roberto Niembro Ortega provides a more conceptual approach that refers to a very sophisticated way in which ruling elites with an authoritarian mentality exercise power in not fully democratic states ${ }^{50}$. Here the regimes do have a liberal democratic constitution, but instead of limiting the power of the state it is used for practical and authoritarian ideological functions to mask the idea of constitutionalism. But, as pointed out earlier, if the constitution does not limit the government's power, it cannot fulfil the requirements of constitutionalism, and can

42 András Sajó and Renáta Uitz, The Constitution of Freedom: An Introduction to Legal Constitutionalism, Oxford University Press, 2017. 13.

${ }^{43}$ In contrast, others also regard other models of constitutionalism, in which the government, although committed to acting under a constitution, is not committed to pursuing liberal democratic values. See for instance Mark Tushnet, Varieties of Constitutionalism, 14 Int'1 J. Const. L. 1 (2016). On 11 October 2019 Tushnet posted the following message to his Facebook page: "My lecture today was on "Varieties of Constitutionalism," and argued that a thin version of constitutionalism requires only (1) that there be some entrenched provisions, (2) that there be some mechanism for resolving disputes about what the law is that is oriented solely to making decision according to law, and (3) that the regime receive popular consent to the regime as a whole measured over some reasonable period of time. (Lots of complexities elided here.) The first subtext, which almost surfaced in the discussion afterwards, is that the Chinese leadership doesn't really have to fear constitutionalism as such (as it seems to do), if the very thin version I outlined counts as constitutionalism (which I think it does). The second subtext is that, if the idea of thin constitutionalism were accepted the way would be open for discussions about whether thin constitutionalism should be thickened (discussions that are harder to have if the idea of constitutionalism is ruled off the table fro the outset)". Similarly, Gila Stopler defines the state of the current Israeli constitutional system as 'semi-liberal constitutionalism'. Cf. Gila Stopler, Constitutional Capture in Israel, ICONnect, August 21, 2017.

44 Tom Ginsburg and Alberto Simpser, Constitutions in Authoritarian Regimes, 2014.

${ }^{45}$ See for instance Alexander Somek, Authoritarian Constitutionalism: Austrian Constitutional Doctrine 1933-1938 and Its Legacy, in Darker Legacies of Law in Europe: The Shadow of National Socialism and Fascism Over Europe and Its legal Traditions (Christian Joerges and Navraj Singh Ghaleigh eds., 2003); Turkuler Isiksel, Between Text and Context: Turkey's Tradition of Authoritarian Constitutionalism, 11 Int'1 J. Const. L. 702 (2013).

${ }^{46}$ Steven Levitsky \& Lucan A. Way, The Rise of Competitive Authoritarianism, 13 Journal of Democracy 51 (2002).

47 Mark Tushnet, Authoritarian Constitutionalism, 100 Cornell Law Review 391 (2015), 391-561.

48 Tushnet provides the following rough definition of authoritarianism: all decisions can potentially be made by a single decision maker (which might be a collective body), whose decisions are both formally and practically unregulated by law. Ibid., 448.

${ }^{49}$ In the case of Singapore Tushnet argues that the government needs to preserve ethnic and religious hamony, without indicating why this goal can only be achieved by authoritarian tools. He mentions Malaysia, Mexico before 2000, Egypt under Mubarak, and Taiwan between 1955 and the late 1980s, and South Korea between 1948 and 1987 as candiates of authoritarian constitutionalism. See ibid., 393.

${ }^{50}$ See Roberto Niembro Ortega, 'Conceptualizing Authoritarian Constitutionalism', Verfassung und Recht in Übersee (VRÜ), 49 (2016), 339-367. 
only be considered as sham constitution ${ }^{51}$, and as a rhetorical tool, just as populism is in the hands of autocrats.

Most of the chapters in a recently published book ${ }^{52}$ - as the editors' preface states - 'challenge the notion of a single 'proper sense' of constitutionalism that is coexistensive with and exhausted by the discrete elements of the liberal paradigm'. In the introductory chapter, Günter Frankenberg argues that 'liberal orthodoxy treats authoritarian constitutionalism not just as a contested concept, but as a mere travesty or deceitful rendition of the rules and principles, values and institutions of what is innocently referred to as 'Western constitutionalism",53.

Referring to Roberto Gargarella's book on Latin American constitutionalism ${ }^{54}$ Frankenberg claims that the orthodoxy gives 'obsessive attention to issues of rights', especially enforceable civil and political rights at the expense of redistributive policies or social entitlements, free and fair election, separation of powers, judicial review. He introduces authoritarian constitutionalism as 'one of modernity's narratives alloying rule and law,' by using Machiavellian constitutional opportunistic technology, like Chinese head of state Xi Jinping observing established constitutional amendment procedure while stripping himself of the existing term limit, or more Hobbesian claim to defend the public good and people's interest, like Hungarian Prime Minister Viktor Orbán referring to European Christian values while denouncing human rights of refugees. ${ }^{55}$

As Helena Alviar Garcia and Michael Wilkinson demonstrate in their contributions to the same book, political authoritarianism entertains an affinity with economic neoliberalism ${ }^{56}$. This can perfectly be proven by the neoliberal economic policy of the current authoritarian regime of Viktor Orbán's Hungary. One of the most tragic historical example of this relationship is the politics of the van Papen government in the last period of the Weimar Republic as clearly seen by Hermann Heller already in $1933^{57}$. Heller claims that Papen wanted the state and the economy to be 'strictly' separated from one another. Legitimising this policy, Carl Schmitt in November 1932 lectured on 'the state and economy,' arguing that the total state makes an attempt to order the economy in an authoritarian way, drawing a sharp line of separation vis-á-vis the economy, although ruling on the other hand with the strongest military means and the means of mass manipulation (Radio, Cinema). ${ }^{58}$ Besides from retreating from economic and social policy, this authoritarian state is also supposed to retreat from socio-cultural policy. Heller concludes that this 'authoritarian liberalism,' which is characterised by the retreat of the authoritarian state from social policy, liberalization of the economy and dictatorial control by the state of politicointellectual functions cannot be ruled in democratic forms, proving the claim made earlier here that not only democracy presupposes liberalism, but there is no liberalism without democracy either. Together

${ }^{51}$ About the concept of sham constitution see David S. Law and Mila Versteeg, Sham Constitutions, 101 Calif. L. Rev. 863 (2013).

${ }^{52}$ Autoritarian Constituionalism. Comparative analysis and Critique (Helena Alviar Garcia and Günter Frankenberg eds., 2019.

${ }^{53}$ See Günter Frankenberg, Authoritarian Constitutionalism: Coming to Terms with Modernity's Nightmares, in Autoritarian Constituionalism. Comparative analysis and Critique (Helena Alviar Garcia and Günter Frankenberg eds., 2019$), 7$.

${ }^{54}$ Cf. Roberto Gargarella, Latin American Constitutionalism 1810-2010: The Engine Room of the Constitution, Oxford University Press, 2013.

55 Günter Frankenberg, Authoritarian Constitutionalism: Coming to Terms with Modernity's Nightmares, in Autoritarian Constituionalism. Comparative analysis and Critique (Helena Alviar Garcia and Günter Frankenberg eds., 2019), 13-17.

${ }^{56}$ See Helena Alvoar Garcia, Neoliberalism As a Form of Auhoritarian Constitutionalism, , in Autoritarian Constituionalism. Comparative analysis and Critique (Helena Alviar Garcia and Günter Frankenberg eds., 2019), 37-56., and Michael A. Wilkinson, Authoritarian Liberalism As Authoritarian Constitutionalism, in Autoritarian Constituionalism. Comparative analysis and Critique (Helena Alviar Garcia and Günter Frankenberg eds., 2019), 317-337.

${ }^{57}$ Cf. Heller's paper on 'Authortarian Liberalism?', which orginally appeard in 1933in vol. 44 of Die Neue Rundschau (289298). See the English translated version in European Law Journal, Vol. 21. No. 3. May 2015. 295-301.

58 Ibid., 299-300. 
with Juan José Linz we can also be skeptical regarding the efforts to distinguish between ostensibly benevolent 'authoritarian, antidemocratic political solution', and totalitarianism in the $1930 \mathrm{~s}^{59}$. Based on the experiences of the current authoritarian regimes, for instance in Russia ${ }^{60}$ I would add the same doubts about the benevolence of 'authoritarian constitutionalism' altogether.

Besides the constitutions in the Communist countries, both current theocratic and communitarian constitutions are considered as illiberal. ${ }^{61}$ Theocratic constitutions, in contrast to modern constitutionalism, reject secular authority. ${ }^{62}$ In communitarian constitutions, like the ones in South Korea, Singapore and Taiwan, the well-being of the nation, the community and society receive utilitarian priority rather than the individual freedom, which is the principle of liberalism. But in these illiberal polities, there is no constitutionalism, their constitutions - using Pablo Castillo-Ortiz's term - are 'denormativised. ${ }^{93}$ In other words, in my view 'illiberal constitutionalism' is an oxymoron.

\section{Can 'Nonliberal Constitutionalism' Be Really Constitutionalist?}

Besides illiberal constitutionalism there are also attempts to legitimate 'nonliberal constitutionalism' as a subtype of constitutionalism. Graham Walker uses the term for constitutionalist structures, 'wherever people value some aspects of communal identity more than autonomy of individual choice. ${ }^{64}$ Walker's main example for the nonliberal, rather local than universal values is the multicultural grant of group right to native peoples and the distinct society of Québec, but he also mentions the state of Israel, which fails its noncitizen residents in many regrettable ways, as well as the tribal life of the native American nations in the US. The common characteristic of all these approaches is 'to indict the notion of individual autonomy rights as a form of naïve and homogenizing universalism, and to unmask the ethnic and moral 'neutrality' of the liberal state as a covert form of coercion. ${ }^{65}$ Walker builds up his concept using Charles Howard McIlwain's understanding of constitutionalism in his 1940 book $^{66}$. According to McIlwain the limitation of government by law isn't necessarily liberal, because the rights of individuals are nor centralized, and there is no need for a public authority to be a neutral arbiter among competing value systems. Among the more contemporary thinkers, Walker relies on Stanley Fish's skepticism about individual rights of all kind. In his notorious articles from $1987^{67}$ and $1992^{68}$ respectively, Fish argues that because liberalism conceives its rational principles precisely as supranational and nonpartisan, 'one can only conclude, and conclude nonparadoxically, that liberalism doesn't exist.' According to Walker, nonliberal constitutionalism historically was anticipated in some features of Republican Rome or of

\footnotetext{
${ }^{22}$ See Juan José Linz, Totalitarian and Authoritarian Regimes, Lynne Rienner, 2000. 51.

${ }^{60}$ Among the Machiavellian technologies Frankenberg mentions the Putin-Medvedev tandemocracy. Günter Frankenberg, Authoritarian Constitutionalism: Coming to Terms with Modernity's Nightmares, in Autoritarian Constituionalism. Comparative analysis and Critique (Helena Alviar Garcia and Günter Frankenberg eds., 2019), 15.

${ }^{61}$ Li-Ann Thio, Constitutionalism in Illiberal Polities, in Oxford Handbook of Comparative Constitutional Law 133 (Michel Rosenfeld, \& András Sajó eds., 2012). Contrary to my understanding, Thio also talks about 'constitutionalism' in illiberal polities.

62 There are two subcategories distinguished here: The Iranian subcategory, where Islam is granted an authoritative central role within the bounds of a constitution; and the Saudi Arabian subcategory, where Islam is present, without the formal authority of modern constitutionalism.

${ }^{63}$ See Pablo Castillo-Ortiz, The Illiberal Abuse of Constitutional Courts in Europe, 15 European Constititonal Law Review, 2019. 48-72, at 67.

${ }^{64}$ Graham Walker, The Idea of Nonliberal Constitutionalism, Nomos

Vol. 39, Ethnicity and Group Rights, 1997. 154-184, at 155.

65 Ibid., 157.

${ }^{66}$ Charles Howard McIlwain, Constitutionalism, Ancient and Modern, Cornell University Press, 1940.

${ }^{67}$ Stanley Fish, Liberalism Doesn't Exist, Duke Law Journal, December 1987.

${ }^{68}$ Stranley Fish, There's No Such Thing as Free Speech and It's a Good Thing, Too, Boston Review 17:1, 1992.
} 
medieval Europe, or in the millet system of the Ottoman Empire, while in more recent history in Canada before the 1982 Charter of Rights and Freedoms. $\mathrm{He}$ also considers the evolving multiculturalist/tolerationist American university campus practices as an embryonic version of nonliberal constitutionalism, and 'politically correct' thinkers who promote such policies as hostile to the notion of 'individual rights.'

The problem with Walker's concept is that he conflates constitutionalism with the constitution. While the latter indeed predates the enlightenment, the former, together with liberalism does not ${ }^{69}$. The 'constitution' as the configuration of public order defined by Aristotle or Cicero did not require the notion of individual rights, while modern constitutionalism does ${ }^{70}$. For instance Montesquieu in The Spirit of Laws argues that the constitutional system based on the separation of power is necessary for securing political liberty and preventing the emergence of 'tyrannical laws' and 'execution of laws in a tyrannical manner. ${ }^{71}$ This means that 'fettered power', which, according to Walker is the essence of constitutionalism, presupposes guaranteed individual rights. In other words, not only the anti- or illiberal version of constitutionalism, discussed earlier, but also the nonliberal one is an oxymoronic.

\section{Attempts to Legitimize 'Illiberal Constitutionalism'}

\section{Majoritarian (Westminster) System}

Proponents of Fidesz' illiberal constitution, as Béla Pokol, professor of law and member of the packed Hungarian Constitutional Court argues that the post-20122 constitutional system envisages the Westminster type of Parliamentary system, in which the 'winner takes all', and where principle of the unity of power prevails ${ }^{72}$. But the Hungarian or for that matter the Polish constitutional system cannot be considered as a monistic democracy, which just gives priority to democratic decision-making over fundamental rights. ${ }^{73}$ Actually, the new Hungarian constitution and the Polish constitutional practice do not comply with any models of government, which are based on the concept of separation of powers. The more traditional models of government forms are based on the relationship between the legislature and the executive. For instance, Arendt Lijphart differentiates between majoritarian (Westminster) and consensual models of democracy, the prototype of the first being the British, while of the second the continental European parliamentary, as well as the U.S. presidential system. ${ }^{74}$ Giovanni Sartori speaks about presidentialism and semi-presidentialism, as well as about two forms of parliamentarism, namely

69 'Classic liberalism' in its $19^{\text {th }}$ centrury European sense means individual liberty and free market. See András Sajó and Renáta Uitz, The Constitution of Freedom: An Introduction to Legal Constitutionalism, Oxford University Press, 2017. 13.

${ }^{70}$ Carl J. Friedrich, one of the authors Walker refers to, in the later editions of his famous text on Constitutional Government and Democracy emhapsizes that the single function of constitutionalism is safeguarding each person in the exercise of 'individual rights.' See Carl J. Friedrich, Constitutional Governance and Democracy: Theory and Practice in Europe and America, $4^{\text {th }}$ ed., Blaisdell, 1968. 24, 7. Walter Murphy, another author, quoted by Walker after the democratic transition in Eastern Europe has also talked about 'protecting individual liberty' as the ultimate civic purpose of constitutionalism. Cf. Walter F- Murphy, Constitutions, Constitutionalism and Democracy, in Douglas Greenberg, Stanley N. Katz, Melanie Beth Oliviero, and Steven D. Wheatley (eds.), Constitutionalism and Democracy: Transitions in the Contemporary World, Oxford University Press, 1993.

${ }^{71}$ Montesquieu, The Spirit of the Laws, (transl. and eds.AM Cohler, BC Miller, HS Stone, Cambridge University Press, 1999. Book XI. Chapter 6 at 157. (Quoted by Gábor Attila Tóth, Constitutional Markers of Authoritarianism, Hague Journal on the Rule of Law, Published online: 10 September 2018.)

72 Béla Pokol, 'Elismerés és kritika’ (Recognition and Criticism), Magyar Nemzet, 2011. március 24.

${ }^{73}$ Bruce Ackerman distinguishes between three models of democracy: Monistic, rights fundamentalism, in which fundamental rights are morally prior to democratic decision-making and impose limits, and dualist, which finds the middle ground between these two extremes, and subjects majoritarian decision-making to constitutional guarantees. See Bruce Ackerman, 1 We the People 6-16 (1992).

${ }^{74}$ Arendt Lijphart, Patterns of Democracy. Government Forms and Performance in Thirty-Six Countries (1999). 
the premiership system in the UK, or Kanzlerdemokratie in Germany, and the assembly government model in Italy. ${ }^{75}$ Bruce Ackerman uses, besides the Westminster and the US separation of powers systems, the constrained parliamentarism model as a new form of separation of powers, which has emerged against the export of the American system in favor of the model of Germany, Italy, Japan, India, Canada, South Africa, and other nations, where both popular referendums and constitutional courts constrain the power of the parliament. ${ }^{76}$

Hungary and Poland, from 1990 until 2010, and 2015 respectively, belonged to the consensual and constrained parliamentary systems, close to the German Kanzlerdemokratie, in Poland with a more substantive role for the President of the Republic. But in Hungary, the 2011 Fundamental Law abolished almost all possibility of institutional consensus and constraints of the governmental power. In Poland, despite the fact that the governmental majority isn't able to change the Constitution, due to the legislative efforts of the PiS government, the 1997 Constitution has become a sham document. In both countries, the system has moved towards an absolute parliamentary sovereignty model without the cultural constrains of the Westminster form of government. Not to mention the fact that in the last decades, the traditional British model of constitutionalism has also been changed drastically with the introduction of a bill of rights by left-of-centre governments - and opposed by right-of-centre opposition parties - in Canada (1982), New Zealand (1990), the United Kingdom (1998), the Australian Capital Territory (2004) and the State of Victoria (2006). Contrary to the traditional Commonwealth model of constitutionalism, in the new Commonwealth model the codified bills of rights became limits on the legislation, but the final word remained in the hands of the politically accountable branch of government. In this respect, this new Commonwealth model is different from the judicial supremacy approach of the US separation of powers model, as well from the European constrained parliamentary model. The biggest change occurred in the UK, and some even talk about the 'demise of the Westminster model' ${ }^{77}$ The greatest deviation from the system of unlimited parliamentary sovereignty was the introduction of judicial review. In just over two decades, the number of applications for judicial review nearly quadrupled to over 3,400 in 2000, when the Human Rights Act 1998 came into effect in England and Wales. ${ }^{78}$ The Human Rights Act has a general requirement that all legislation should be compatible with the European Convention of Human Rights. This does not allow UK courts to strike down, or 'disapply', legislation, or to make new law. Instead, where legislation is deemed to be incompatible with Convention rights, superior courts may make a declaration of incompatibility under Section 4.2. Then, the government and Parliament decide how to proceed. In this sense, the legislative sovereignty of the UK Parliament is preserved. Some academics argue that, although as a matter of constitutional legality Parliament may well be sovereign, as a matter of constitutional practice it has transferred significant power to the judiciary. ${ }^{79}$

Others go even further and argue that, although the Human Rights Act 1998 is purported to reconcile the protection of human rights with the sovereignty of Parliament, it represents an unprecedented transfer of political power from the executive and legislature to the judiciary. ${ }^{80}$

Besides the mentioned Commonwealth countries, a similarly new model has emerged in Israel, where the Basic Law on occupation, re-enacted in 1994, contains a 'notwithstanding' provision, similar to the Canadian one. The new model of Commonwealth constitutionalism is based on a dialogue between the

\footnotetext{
75 Giovanni Sartori, Comparative Constitutional Engineering (2nd ed., 1997).

${ }^{76}$ Bruce Ackerman, The New Separation of Powers, 113 Harv. L. Rev. 633 (2000).

77 Cf. Philip Norton, Governing Alone, Parliamentary Affairs, October 2003, 544.

${ }^{78}$ See David Judge, Whatever Happened to Parliamentary Democracy in the United Kingdom, Parliamentary Affairs, July 2004, 691.

${ }^{79}$ Cf. Keith D. Ewing, The Human Rights Act and Parliamentary Democracy, 62 Modern L. Rev. 79, 92 (1999).

${ }^{80}$ See Matthew Flinders, Shifting the Balance? Parliament, the Executive and the British Constitution, Political Studies, March 2002, 62 .
} 
judiciary and the parliament. In contrast to these new trends, in the Hungarian and Polish constitutional system the parliamentary majority not only decides every single issue without any dialogue, but practically there is no partner for such a dialogue, due to the fact that the independence of both the ordinary judiciary and the constitutional courts have been eliminated.

\section{Political Constitutionalism}

It is striking, and of significance, how the illiberal authoritarians in Central and Eastern Europe attempt to legitimize their actions by referring to political constitutionalism as their approach to constitutional change. The main argument of Central and Eastern European illiberals to defend their constitutional projects is grounded in a claim to political constitutionalism, which favors parliamentary rule and weak judicial review. To be clear, despite some academics' efforts to apply the concept of political constitutionalism in defense of illiberalism, I do not consider political constitutionalism, based on republican philosophy, or all of the concepts rejecting strong judicial review, or judicial review altogether, as populist. ${ }^{81}$ Some scholars and constitutional court justices both in Hungary and Poland have attempted to interpret the new constitutional system as a change from legal to political constitutionalism. In my view, these interpretations are simply efforts to legitimize the silencing of judicial review.

One of the 'fake judges' of the Polish Constitutional Tribunal, the late Lech Morawski, emphasized the republican traditions, present both in Hungary and Poland, mentioning the names of Michael Sandel, Philip Pettit, and Quentin Skinner. ${ }^{82}$ Also, constitutional law professor Adam Czarnota explained the necessity of the changes, with the argument that 'legal constitutionalism alienated the constitution from citizens... The place of excluded citizens was taken by lawyers. ${ }^{83}$ He proudly acknowledges that the governing party, PiS has appointed judges that represent its worldview, which according to Czarnota is based 'on the principle of supremacy of the Parliament in relation to constitutional review and acceptance of a role of the judicial restraint not judicial activism which was earlier the norm. ${ }^{, 84}$ Czarnota interprets the present constitutional crisis in Poland and in some other countries in Central-Eastern Europe as 'an attempt to take the constitution seriously and return it to the citizens, ${ }^{85}$ what he considers the fulfillment of political constitutionalism.

In Hungary, István Stumpf, constitutional judge, nominated without any consultation with opposition parties by FIDESZ right after the new government took over in 2010, and elected exclusively with the votes of the governing parties' votes, in his book argued for a strong state and claimed the expansion of political constitutionalism regarding the changes ${ }^{86}$ It is remarkable that two other members of the current packed Constitutional Court also argue against legal constitutionalism, blaming it as 'judicial dictatorship ${ }^{97}$ or 'juristocractic. ${ }^{98}$ In the scholarly literature, Attila Vincze argued that the decision of the Constitutional Court accepting the Fourth Amendment to the Fundamental Law-which among other things also invalidated the entire case-law of the Court prior to the new constitution —was a sign

\footnotetext{
${ }^{81}$ See for the opposite view Lucia Corso, What Does Populism Have to Do with Constitutional Law? Discussing Populist Constitutionalism and Its Assumptions, Rivista di filosofia del Diritto 443 (2014).

82 Lech Morawski, A Critical Response, Verfassungsblog, June 3, 2017.

83 Adam Czarnota, The Constitutional Tribunal, Verfassungsblog, June 3, 2017.

${ }^{84}$ Ibid.

${ }^{85}$ Ibid.

${ }^{86}$ See István Stumpf, Erős Állam - Alkotmányos Korlátok [Strong State - Constitutional Limits] 244-249 (2014).

${ }^{87}$ See András. Zs. Varga, From Ideal to Idol? The Concept of the Rule of Law, Dialóg Campus, Budapest, 2019. 16.

${ }^{88}$ Béla Pokol, The Juristocratic State: Its Victory and the Possibility of Taming. Budapest, Dialóg Campus, Budapest, 2017.
} 
of political constitutionalism prevailing over the legal one. ${ }^{89}$ Even those, like Kálmán Pócza, Gábor Dobos and Attila Gyulai who acknowledge that the Court hasn't been confrontational towards the current legislature and the government characterize this behavior as a special approach within the system of separation of powers, best described as a partnership in a constitutional dialogue ${ }^{90}$.

Political constitutionalists, like Richard Bellamy, Jeremy Waldron, Akhil Amar, Sandy Levinson, and Mark Tushnet, who themselves differ from one another significantly, emphasize the role of elected bodies instead of courts in implementing and protecting the constitution, but none of them reject the main principles of constitutional democracy, as 'illiberal' populist constitutionalists do. Even Richard D. Parker, who announced a 'constitutional populist manifesto' wanted only to challenge the basic idea, central to constitutional law, 'that constitutional constraints on public power in a democracy are meant to contain or tame the exertion of popular political energy rather than to nurture, galvanize, and release it. ${ }^{91}$ Similarly, those who describe a new model of constitutionalism, based on deliberation between courts and the legislator, with the latter retaining the final word, have nothing to do with illiberal constitutionalism. ${ }^{2}$ Those scholars realize that parliamentary sovereignty tends to be increasingly restrained, either legally or politically, and that the last decades have witnessed less and less scope for the exercise of traditional pouvoir constituant, conceived as the unrestrained 'will of the people', even in cases of regime change or the establishment of substantially and formally new constitutional arrangements. ${ }^{93}$ The remainders of both Hungarian and Polish constitutional review have nothing to do with any types of political constitutionalism or a weak judicial review approach, which all represent a different model of separation of powers. In the authoritarian Hungarian and in the Polish sham system of constitutionalism, there is no place for any kind of separation of powers.

Following Tamás Györfi's theory, there are three different forms of weak judicial review: each of them is lacking one of the defining features of strong constitutional review, but all of them want to strike a

${ }^{89}$ Attila Vincze, Az Alkotmánybíróság határozata az Alaptörvény negyedik módosításáról: az alkotmánymódosítás alkotmánybírósági kontrollja [The Decision of the Constitutional Court on the Fourth Amendment to the Fundamental Law: The Constitutional Review of Constitutional Amendments], Jogesetek Magyarázata 3, 12 (2013).

${ }^{90}$ See K. Pócza - G. Dobos - A. Gyulai, 'The Hungarian Constitutional Court: A constructive partner in constitutional dialogue', in K. Pócza (ed.), Constitutional Politics and the Judiciary. Decision-Making in Central and Eastern Europe, Routledge, 2018. Chapter 5.

${ }^{91}$ Analyzing Thomas Mann's novel Mario and the Magician, written in 1929, Parker draws the conclusion for today that, "the point is to get out and take part in politics ourselves, not looking down from a 'higher' pedestal, but on the same level with all of the other ordinary people.” Richard D. Parker, 'Here, the People Rule': A Constitutional Populist Manifesto, 27 Valparaiso Univ. L. Rev. 583, 531-584 (1993). A similar message can be detected in the interview with Mark Lilla, a conservative liberal professor of the humanities at Columbia University, who on the day after Donald Trump's presidential victory declared: "One of the many lessons of the recent presidential election and its repugnant outcome is that the age of identity liberalism must be brought to an end." Mark Lilla, The End of Identity Liberalism. The New York Times, November 18, 2016. Later, in an interview on the topic of the most effective tools against the President's populism, Lilla emphasized the importance that opponents find a way to unify: "We have to abandon the rhetoric of difference, in order to appeal to what we share." David Remnick, A Conversation with Mark Lilla on His Critique of Identity Politics, The New Yorker, Aug. 25, 2017.

${ }^{92}$ See Stephen Gardbaum, The Commonwealth Model of Constitutionalism. Theory and Practice (2013) about the new model. This model has also come to be known by several other names: "weak-form of judicial review" (Mark Tushnet, Alternative Forms of Judicial Review, 101 Michigan L. Rev. 2781 (2003)); "weak judicial review" (Jeremy Waldron, The Core of the Case Against Judicial Review, 115 Yale L. J. 1348 (2006)); "the parliamentary bill of rights model" (Janet Hiebert, Parliamentary Bill of Rights. An Alternative Model?, 69 Modern L. Rev. 7 (2006)); "the model of democratic dialogue" (Alison L. Young, Parliamentrary Sovereignty And The Human Rights Act (2009)); "dialogic judicial review" (Kent Roach, Dialogic Judicial Review and its Critics, 23 Supreme Court Law Review, 2nd series 49 (2004)); "collaborative constitution" (Aileen Kavanaugh, Participation and Judicial Review: A Reply to Jeremy Waldron, 22 Law and Philosophy 451 (2003)); or "democratic constitutionalism" (Robert Post - Reva Siegel, Democratic Constitutionalism, White Paper, https://constitutioncenter.org/interactive-constitution/white-pages/democratic-constitutionalism)).

${ }^{93}$ Carlo Fusaro \& Dawn Oliver, Towards a Theory of Constitutional Change', in How Constitutions Change - A Comparative Study (Dawn Oliver \& Carlo Fusaro eds., 2011). 
balance between democracy and the protection of human rights that differs from the balance struck by the 'new constitutionalism' of strong judicial review. ${ }^{94}$ First, judicial review is limited if the constitution lacks a bill of rights, as is the case in Australia. Second, judicial review is deferential if courts usually defer to the views of the elected branches, as in the Scandinavian constitutional systems, or are even constitutionally obliged to do so, as in Sweden and Finland. Finally, and probably most importantly, there is the Commonwealth model of judicial review, where courts are authorized to review legislation, but the legislature has the possibility to override or disregard judicial decisions. ${ }^{95}$

In my view, neither the Polish nor the Hungarian model fits any of these approaches to weak judicial review, as their aim is neither to balance democracy nor the protection of fundamental rights. The weakening of the power of constitutional courts has started in Hungary right after the landslide victory of the center-right FIDESZ party in the 2010 parliamentary elections. What happened in Hungary resonated with some less successful, similar attempts to weaken constitutional review in other EastCentral European countries that took place roughly around the same time. In the Summer of 2012, there was a constitutional crisis also in Romania, where the ruling socialists tried to dismantle both the constitutional court and the president, but the EU was able to exert a stronger influence over events there. ${ }^{96}$ From 2014, there has also been a constitutional crisis in progress in Slovakia, where the Constitutional Court has also worked with two - and from February 2016 three-judges short, because the President of the Republic refused to fill the vacancies. ${ }^{97}$ But the most successful follower of the Hungarian playbook on how to dismantle constitutional review has been Jaroslaw Kaczynski's governing party (PiS) and its government in Poland. After the 2015 parliamentary election in Poland, the Law and Justice Party (PiS) also followed the playbook of Viktor Orbán, and started by first capturing the Constitutional Tribunal. ${ }^{98}$ But these efforts have nothing to do with political constitutionalism, partly because they do not question the capacity of constitutional courts to invalidate legislation passed by parliaments, partly because they are not based on the mechanism of political accountability and checks on power. ${ }^{99}$ Also, political constitutionalism emphasises the importance of legislatures over courts, and not the direct role of citizens, as Czarnota argues. This dismantlement of constitutional review cannot be considered as a par excellence majoritarian project either. ${ }^{100}$

\section{Constitutional Identity}

From the very beginning, the government of Viktor Orbán has justified non-compliance with the principles of liberal democratic constitutionalism enshrined also in Article 2 of the Treaty of the European Union (TEU) by referring to national sovereignty. ${ }^{101}$ Lately, as an immediate reaction to the

${ }^{94}$ See Tamás. Györfi, Against The New Constitutionalism (2016).

95 See Gardbaum, supra note 62.

${ }^{96}$ About the Romanian crisis see Vlad Perju, The Romanian double executive and the 2012 constitutional crisis, 13 Int'l J. of Constitutional L. 246-278 (2015); Bogdan Iancu, Separation of Powers and the Rule of Law in Romania: The Crisis in Concepts and Contexts, in Constitutional Crisis In The European Constitutional Area 153 (Armin von Bogdandy \& Pál Sonnevend eds., 2015).

97 Tomás Lálik, Constitutional Crisis in Slovakia: Still Far from Resolution, ICONect, August 5, 2016. http://www.iconnectblog.com/2016/08/constitutional-court-crisis-in-slovakia-still-far-away-from-resolution/.

98 The same playbook was also used outside the region, in Turkey by Erdoğan and in Venezuela by Chavez.

${ }^{99}$ See this requirements of political constitutionalism in Pablo Castillo-Ortiz, The Illiberal Abuse of Constitutional Courts in Europe, 15 European Constititonal Law Review, 2019. 48-72, at 64.

100 As Wojciech Sadurski rightly points out the Polish governing party, PiS obtained $18 \%$ of the votes of all eligible voters. See Wojciech Sadurski, Poland's Constitutional Breakdown, Oxford Univesity Press, 2019. 1.

101 The first reaction of the Hungarian government to the so called 'Tavares report' of 3 July 2013 of the European Parliament on the Hungarian constitutional situation (http://www.europarl.europa.eu/sides/getDoc.do?type=REPORT\&reference=A72013-0229\&language=EN) was not a sign of willingness to comply with the recommendations of the report, but rather a harsh rejection. Two days after the European Parliament adopted the report at its plenary session, the Hungarian Parliament 
EU's efforts to solve the refugee crisis, the government has advanced the argument that the country's constitutional identity is guaranteed in Article 4 (2) TEU.

After some draconian legislative measures were adopted, the government started a campaign against the EU's plan to relocate refugees. The first step was a referendum initiated by the government. On 2 October 2016, Hungarian voters went to the polls to answer one referendum question: 'Do you want to allow the European Union to mandate the relocation of non-Hungarian citizens to Hungary without the approval of the National Assembly?' Although $92 \%$ of those who casted votes and $98 \%$ of all the valid votes agreed with the government, answering 'no' ( $6 \%$ were spoiled ballots), the referendum was invalid because the turnout was only around $40 \%$, instead of the required $50 \%$.

As a next attempt, Prime Minister Orbán introduced the Seventh Amendment, which would have made it 'the responsibility of every state institution to defend Hungary's constitutional identity'. The most important provision of the draft amendment reads: 'No foreign population can settle in Hungary'. Since the governing coalition lost its two-thirds majority, even though all of its MPs voted in favour of the proposed amendment, it fell two votes short of the required majority. After this second failure, the Constitutional Court, loyal to the government, came to the rescue of Orbán's constitutional identity defence of its policies on migration. The Court revived a petition of the also loyal Commissioner for Fundamental Rights, filed a year earlier, before the referendum was initiated. In his motion, the Commissioner asked the Court to deliver an abstract interpretation of the Fundamental Law in connection with the Council Decision 2015/1601 of 22 September 2015.

The Constitutional Court in its decision held that 'the constitutional self-identity of Hungary is a fundamental value not created by the Fundamental Law - it is merely acknowledged by the Fundamental Law, consequently constitutional identity cannot be waived by way of an international treaty'. ${ }^{102}$ Therefore, the Court argued, 'the protection of the constitutional identity shall remain the duty of the Constitutional Court as long as Hungary is a sovereign State'. ${ }^{103}$ This abuse of constitutional identity aimed at not taking part in the joint European solution to the refugee crisis is an exercise of national constitutional parochialism, ${ }^{104}$ which attempts to abandon the common European liberal democratic constitutional whole.

adopted Resolution 69/2013 on 'the equal treatment due to Hungary'. The document is written in first person plural as an anti-European manifesto on behalf of all Hungarians: 'We, Hungarians, do not want a Europe any longer where freedom is limited and not widened. We do not want a Europe any longer where the Greater abuses his power, where national sovereignty is violated and where the Smaller has to respect the Greater. We have had enough of dictatorship after 40 years behind the iron curtain.' The resolution argues that the European Parliament exceeded its jurisdiction by passing the report, and creating institutions that violate Hungary's sovereignty as guaranteed in the Treaty on the European Union. The Hungarian text also points out that behind this abuse of power there are business interests, which were violated by the Hungarian government by reducing the costs of energy paid by families, which could undermine the interest of many European companies which for years have gained extra profits from their monopoly in Hungary. In its conclusion, the Hungarian Parliament called on the Hungarian government 'not to cede to the pressure of the European Union, not to let the nation's rights guaranteed in the fundamental treaty be violated, and to continue the politics of improving life for Hungarian families'. These words very much reflect the Orbán government's view of 'national freedom', which emphasizes the liberty of the state (or the nation) to determine its own laws: 'This is why we are writing our own constitution...And we don't want any unsolicited help from strangers who are keen to guide us...Hungary must turn on its own axis'. (For the original, Hungarian-language text of Orbán's speech, entitled Nem leszünk gyarmat! [We won’t be a colony anymore!] see e.g. <http://www.miniszterelnok.hu/beszed/nem_leszunk_gyarmat_The English-language translation of excerpts from Orbán's speech was made available by Hungarian officials, see e.g. Financial Times: Brussels Blog, 16 March 2012, at: $<$ http://blogs.ft.com/brusselsblog/2012/03/the-eu-soviet-barroso-takes-on-hungarysorban/?catid=147\&SID=google\#axzz1qDsigFtC $>$ ).

102 Decision 22/2016 AB of the Constitutional Court of Hungary [67]. See a detailed analysis of the decision G. Halmai, 'Abuse of Constitutional Identity. The Hungarian Constitutional Court on Interpretation of Article E) (2) of the Fundamental Law, Review of Central and East European Law, 43 (2018), 23-42.

103 Ibid.

${ }^{104}$ See the term used by M. Kumm, 'Rethinking Constitutional Authority: On Structure and Limits of Constitutional Pluralism', in M. Avbelj and J. Komárek, Constitutional Pluralism in the European Union and Beyond, Hart, 2012. 51. 
The Constitutional Court in its decision 3/2019. (III. 7.) $\mathrm{AB}$ also decided about the constitutionality of certain elements of the Stop Soros legislative package, and ruled that the criminalization of 'facilitating illegal immigration' does not violate the Fundamental Law. The Court again referred to the constitutional requirement to protect Hungary's sovereignty and constitutional identity to justify this clear violation of freedom of association, freedom of expression hiding behind the alleged obligation to protect Schengen borders against 'masses entering uncontrollably and illegitimately' the EU ${ }^{105}$. Besides infringing the rights of the NGOs, the decision deprives all asylum seekers of the protection of all fundamental rights by stating that ,the fundamental rights protection ... clearly does not cover the persons arrived in the territory of Hungary through any country where he or she had not been persecuted or directly threatened with persecution. Therefore, the requirements set forth by Article I Paragraph (3) of the Fundamental Law regarding the restriction of fundamental rights shall not be applied to the regulation of the above listed cases ${ }^{106}$. With this the Court denies the core of human dignity: the right to have rights.

\section{Illiberal Societies}

\section{Social Relations}

Historically, in the East-Central European countries there were only some unexpected moments of quick flourishing of liberalism and liberal democracy followed by an equally quick delegitimization of it. For instance shortly after 1945, till the communist parties took over, and also after 1989, when liberal democracy again seemed to be the 'end of history'. ${ }^{107}$ Otherwise, in the national history of the Central and Eastern European countries' authoritarianism, such as the pre-1939 authoritarian Hungarian or Polish politics, played a much more important role in the transformation. ${ }^{108}$ Maybe the only exception was the independent Czechoslovakia established after WWI, led by its first President Tomáš Garrigue Masaryk $^{109}$.

As mentioned earlier, modernization is the main enemy of illiberal theory. As surveys on the links between modernization and democracy show, the society's historic and religious heritage leaves a lasting imprint. ${ }^{110}$ According to these surveys, the public of formerly agrarian societies, like many of the East Central European ones emphasize religion, national pride, obedience, and respect for authority, while the publics of industrial societies emphasize secularism, cosmopolitanism, autonomy, and rationality. ${ }^{111}$ Even modernization's changes are not irreversible: economic collapse can reverse them,

105 Para [43] of 3/2019. (III. 7.) AB.

106 Ibid. [49].

107 See the results of the research project "Negotiating Modernity": History of Modern Political Thought in East-Central Europe, led by Balázs Trencsényi, and supported by the European Research Council, https://erc.europa.eu/“negotiatingmodernity"-history-modern-political-thought-east-central-europe

108 See Slomo Avineri, Two Decades After the Fall: Between Utopian Hopes and the Burdens of History, Dissent, 30 September 2009.

109 When the preamble of the 1992 Czech constitution incorporated the principle of a civic nation "in the spirit of the inviolable values of human dignity and freedom as the home of equal and free citizens", it was a hint to Masaryk's belief in the universal validity and critical power of democracy and liberty elaborated in his study on The Czech Question. See J. Přibán̆, The Defence of Constitutionalism. The Czech Question in Post-national Europe, and Karolinum Press, Charles University, 2017. 115-116.

${ }^{110}$ See R. Inglehart \& C. Welzel, 'Changing Mass Priorities: The Link between Modernization and Democracy', Perspectives on Politics, 2010, Vol. 8, No. 2, pp. 551-567.

${ }^{111}$ Id., p. 553. This is one of the reason of Czechia's less religious society. Christian Welzel in his more recent book argues that fading existential pressures open people's minds, making them prioritize freedom over security, autonomy over authority, diversity over uniformity and creativity over discipline, tolerance and solidarity over discrimination and hostility against out-groups. On the other hand, persistent existential pressures keep people's mind closed, in which case they 
as happened during the early 1990s in most former communist states. These findings were confirmed by another international comparative study conducted by researchers of Jacobs University in Bremen and published by the German Bertelsmann Foundation. ${ }^{12}$ According to the study, which examined 34 countries in the EU and the OECD, countries in East Central Europe have had a low level of social cohesion ever since the postcommunist transformation, Hungary is ranked at $27^{\text {th }}$, between Poland and Slovakia. Social cohesion is defined as the special quality with which members of a community live and work together. Even though the transition to democracy in East Central Europe was driven by the fact that a large share of the population gave high priority to freedom itself, but people expected the new states to produce speedy economic growth, with which the country could attain the living standards of West preferably overnight, without painful reforms ${ }^{113}$. In other words, one can argue that the average people in these countries pursued the West in 1989-1990, though not so much in terms of the Western political and constitutional system, but rather in terms of the living standards of the West. Claus Offe predicted the possible backsliding effect of the economic changes and decline in living standards, saying that this could undermine the legitimacy of democratic institutions and turn back the process of democratization. ${ }^{14}$ This failure, together with the emergence of an economically and politically independent bourgeoisie, the accumulation of wealth by some former members of the communist nomenclature, unresolved issues in dealing with the communist past, the lack of retributive justice against perpetrators of grave human rights violations, and a mild vetting procedure and lack of restitution of the confiscated properties, were reasons for disappointment. Again, Czechia has been different both regarding the bourgeoisie and the harsher transitional justice measures.

Trying to explain the attitudes of voters to support authoritarian pursuit of illiberal leaders, such as Orbán or Kaczyński, Ronald Inglehart and Pippa Norris suggests that it would be a mistake to attribute the rise of authoritarian populism directly to economic inequality alone, as psychological factors seem to play an even more important role. Older and less-educated people tend to support populist parties and leaders that defend traditional cultural values and emphasize nationalistic and xenophobia appeals, rejecting outsiders, and upholding old-fashioned gender roles. ${ }^{115}$ Similarly, Will Wilkinson argues that urbanisation is a process that divides society in cultural values. While it creates thriving, multicultural, high-density areas where socially liberal values predominate, it also leaves behind rural areas and smaller urban centres that are increasingly uniform in terms of rather illiberal values. ${ }^{116}$

Interestingly enough a more recent research of Christian Welzel and Plamen Akaliyski have a slightly different evaluation about the cultural values of East-Central European countries after the democratic transition, questioning, whether the cultural walls still stands between East and West of the former Iron Curtain $^{117}$. They claim that countries that joined the European Union have converged significantly towards the cultural model of the core of EU member states., while European countries that remained outside the EU have shifted their cultural values away from this EU core.

emphasize the opposite priorities. This is the utility ladder of freedom. Ch. Welzel, Freedom Rising. Human Empowerment and the Quest for Emancipation, Cambridge University Press, 2013.

${ }^{112}$ D. Schiefer, J. van der Noll, J. Delhey, \& K. Boehnke, Cohesion Radar: Measuring Cohesiveness, Bertelsmann Foundation, 2013, <www.bertelsmann-stiftung.de/bst/en/media/xcms_bst_dms_36378_2.pdf>

113 As Ulrich Preuss argues, the satisfaction of the basic economic needs of the populace was so important for both the ordinary people and the new political elites that constitutions did not really make a difference. See U. K. Preuss, Constitutional Revolution. The Link Between Constitutionalism and Progress. Humanities Press. 1993, 3.

${ }^{114}$ Cf. C. Offe, Designing Institutions for East European Transitions, Institut für Höhere Studies, 1994. 15.

${ }^{115}$ R. Inglehart and P. Norris, Culktural Backlash, Trump, Brexit, and Authoritarian Populism, Cambridge University Press, 2019.

${ }^{116}$ W. Wilkinson, The Density Divide: Urbanization, Polarization, and Populist Backlash, Research Paper of the Niskanen Center, June 2018.

117 Plamen Akaliyski and Christian Welzel, 'Clashing Values: Cultural and Geoplolitical Transformation of Post-Cold War Europe’, World Values Research, Volume 11/Number 4/2019. 85-123. 
A recent Eurobarometer survey conducted in April 2019 proved the observation of Akaliyski and Welzel even in the case of Hungary and Poland, the most illiberal EU member states, at least regarding values related to the rule of law, democracy and fundamental rights. People in these countries acknowledge both the importance of independent constitutional institutions, including judicial review and court, as well as that all state institutions respect court rulings, and the need for improvement on these fields. When asked about the importance of 'that all member states respect the core values of the EU, including fundamental rights, the rule of law, and democracy' $31 \%$ of Poles found this essential, 53\% important, in Hungary the same figures were 55 and $37 \%$ respectively, which is even higher than the average of the $28 \mathrm{EU}$ member states (53 and 36\% respectively). Whether certain elements of these, for instance 'if your rights are not respected, you can have them upheld by an independent court' need to be improved 32 and $44 \%$ of the Poles, while the 54 and 35\% of Hungarians (again above the EU average of 50 and $30 \%$ ) said it definitely or somewhat can. ${ }^{118}$

This relatively high awareness of the importance and the need of improvement of values such fundamental rights, the rule of law and democracy is hardly reconcilable with the continuous support especially in the rural areas, mentioned by Will Wilkinson - of the authoritarian governments of Hungary and Poland, which openly defy these values. ${ }^{119}$ Here I cannot even try to fully explain all the possible reasons of this discrepancy. In Hungary one of them is certainly due to the lack of the independent media, and the freedom of civil society organisations people, even though admitting the necessity of improvement in complying with European values people do not necessarily recognise the autocratic pursuits of the government. Morover, in Poland neither the media nor civil society organisation have yet been dismantled. Here, the main reason of the support of the authoritarian government may lie in the very popular social benefits. In 2016 the PiS government introduced a child benefits programme called '500+': all parents get 500 Polish zloty (about 115 Euros) per month per child, from the second child on. Low-income families got it from the first child. In early 2019, Jaroslaw Kaczyński, the leader of PiS announced another set of social benefits: a monthly 500 zloty for each child, the increase of pension benefits and tax levies for persons under 26 years of age ${ }^{120}$.

\footnotetext{
${ }^{118} \mathrm{http} / / /$ ec.europa.eu/commfrontoffice/publicopinion/index.cfm/survey/getsurveydetail/instruments/special/surveyky/2235. Here are some other some other data on the importance and need of improvement of certain rule of law issues. 1 . When asked about the importance of having independent controls ensuring that laws can be challenged and tested, 28\% of the Polish and 55\% of the Hungarian people believe it essential and 57 and 36\% respectively important (the average results for the whole EU are $49 \%$ and $41 \%$ respectively). When asked whether this particular issue can be improved $26 \%$ of the Polish and 50\% of the Hungarian respondents replied that it definitely can and 48 and 36\% respectively said it somewhat can (the average results for the whole EU are $49 \%$ and $33 \%$ respectively). $2.41 \%$ of the Polish and $61 \%$ of the Hungarian respondents believe it essential, and 49 and $32 \%$ respectively important that judges are independent and not under the influence of politicians or economic interests (the average results for the whole EU are $65 \%$ and $29 \%$ respectively). Whereas $35 \%$ of the Poles and $54 \%$ of the Hungarians assert that it's definitely essential that this issue should be improved, 45 and $35 \%$ respectively thereof believe that it is somewhat important that this should be improved (the average results for the whole EU are 51\% and 31\% respectively). 3. When it comes to assessing the importance of public authorities and politicians respecting and applying court rulings, 39\% of the Polish and 59\% of the Hungarian people deem it essential whilst 52 and 33\% respectively important (the average results for the whole EU are $60 \%$ and $34 \%$ respectively). $34 \%$ of the Polish and $52 \%$ of the Hungarian respondents indicated that it can definitely and 44 and $37 \%$ respectively that it can somewhat be improved.

119 According to Politico's Poll of Polls polling projection, the support of PiS, the Polish governing party was at $47 \%$ on 25 September 2019 (https://www.politico.eu/europe-poll-of-polls/poland/), while that of Fidesz, the Hungarian ruling party at 53\% in 15 September 2019 https://www.politico.eu/europe-poll-of-polls/hungary/.

${ }^{120} \mathrm{See}$ https://www.reuters.com/article/us-poland-politics-childbenefits/child-benefits-and-tax-breaks-as-polish-governmentgears-up-for-election-idUSKCN1TS24G
} 


\section{Economic Relations}

Paradoxically, politically illiberal leaders, like Viktor Orbán of Hungary use (neo)liberal economic policy to support their autocratic (constitutional) agenda ${ }^{121}$. As many argue refering to Karl Polányi's influencial book, The Great Repression the resistance to social democracy through authoritarianism in the name of economic liberalism prepared the ground for Fascism, and can lead to autocracy again ${ }^{122}$.

While other, mostly left-wing populists react to the unfulfilled promise of social-rights constitutionalism, based on T.H. Marshall's concept of social rights being continuous to civil and political rights, which turned out to be a lie in most of East Central European countries' constitutional practice. ${ }^{123}$ As Samuel Moyn argues, a commitment to material equality disappeared, in its place market fundamentalism has emerged as the dominant force of national and global economics ${ }^{124}$.

The new illiberal system of 'national cooperation' in Hungary has left behind the vulnerable members of society, homeless people and refugees, and tries to diminish or cut the solidary actions of the members of the Hungarian society. In this respect Orbán's right-wing authoritarian populism even differs from the policy of other right-wing populists, such as the French National Front or Austria's Freedom Party, who - similarly to Orbán - mobilize their supporters with exclusion through immigration policy, but as opposed to the Hungarian PM, they often also emphasize inclusion through social rights and economic security ${ }^{125}$.

The packed Hungarian Constitutional Court rubberstamps the government's neoliberal economic policy, changing its predecessor's practice, which in the mid 1990's was willing to strike down austerity measures for the protection of social rights closely tying them to the protection of equal human dignity. Although social solidarity was an underdeveloped societal practice from the beginning of the democratic transition for several reasons, the that time Constitutional Court strongly committed itself to the protection of human dignity and this way guaranteed a higher profile for social (solidarity) rights, especially in case of social care based on neediness.

Then, as a contrast, in the 'non-solidary' system of the Hungarian Fundamental Law of 2011 social security does not appear as a fundamental right, but merely as something the state 'shall strive' for, which is a step backward in comparison with the 1989 Constitution. Social insurance is not a constitutional institution any more, and the provisions of the Fundamental Law do not guarantee equal dignity and the former level of property protection. The recent case law of the Constitutional Court

121 This phenomena is called by Michael Wilkinson as authoritarian liberalism. See M. A. Wilkinson, 'Authoritarian Liberalism aa Authoritarian Constitutionalism', in H. Alviar and G. Frankenberg (eds.), Authoritarian Constitutionalism, Edward Elgar, 2019.

${ }^{122}$ See Wilkinson, ibid, and also B. Bugaric,' The Two Faces of Populism:

Between Authoritarian and Democratic Populism', 20 German Law Journal, No. 3. 2019.

${ }^{123}$ Andrew Arato and Jean Cohen, analysing the normative theory of left populist, Ernesto Laclau and Chantal Mouffe respectively go even further by claiming that left populism also cannot avoid the authoritarianism inherent in the strategy and logic of populism despite the inclusionary and democratizing projects of the left movements it attaches to and despite the democratic socialist rhetoric of left populist leaders and their organic intellectuals. See Andrew Arato, 'Political Theology and Populism', Social Research, Vol. 80: No. 1. Spring 2013., as well as Andrew Arato, 'Socialism and Populism,' Constellations, 2019: 26., and Jean L. Cohen, 'What's Wrong with the Normative Theory (and the Actual Preactice) of Left Populism?', Constellations, 2019: 26. In my view it is certainly true for Latin Amarican populist from Peron through Morales, Correa, till Chavez and Maduro, but not necessarily for European left populist parties, such as Podemes, Five Star and Syriza. The last two did not even show serious authoritarian pursuits while being in power. One of the proofs provided by Andrew Arato himself in a paper, in which he discusses how populist governments dismantle constitutional courts. None of the European left populist governments are subject of the comaparison. See. Andrew Arato, 'Populism, Constitutional Courts and Civil Society', in Christine Langfried (ed.), Judicial Power: How Constitutional Courts Affect Political Transformations, Cambridge University Press, 2019. 318-341.

${ }^{124}$ S. Moyn, Not Enough. Human Rights in an Unequal World, Harvard University press, 2018.

125 See A. Weale, The Will of the People. A Modern Myth, Polity, 2018. 40-42. 
reaffirms the initial concerns, the dignity supported social solidarity got lost in the illiberal backsliding of the past ten years.

\section{Political Relations}

The expansion of political illiberalism in East Central Europe through the introduction of a new illiberal constitutional regime went the furthest in Hungary and Poland. In the case of the former through a brandnew constitution enacted in 2010 , or through legislative changes that ignore the valid liberal constitution, as is the case in Poland since 2015. Ironically, both countries are still members of the European Union, a value community based on the principles of liberal democracy.

\section{Hungary}

The new constitution, entitled the Fundamental Law of Hungary was passed by the Parliament on 18 April 2011. ${ }^{126}$ The drafting of the Fundamental Law took place without following any of the elementary political, professional, scientific and social debates. These requirements stem from the applicable constitutional norms and those rules of the House of Parliament that one would expect to be met in a debate concerning a document that will define the life of the country over the long term. The debate, which lasted for nine days - effectively - took place with the sole and exclusive participation of representatives of the governing political parties. ${ }^{127}$

Here I address some of those flaws in its content in relation to which the suspicion arises that they may permit exceptions to the European requirements of democracy, constitutionalism and the protection of fundamental rights, and, thus, that in the course of their application they could conflict with Hungary's international obligations.

1. Government without checks ${ }^{128}$. The new constitution appears to still contain the key features of constitutional constraint imposed by checked and balanced powers. But those constraints are largely illusory, because key veto points have been abolished or seriously weakened. Appointments to key offices, like Constitutional Court judgeships, ombudsmen, the head of the State Audit Office and the public prosecutor, no longer require minority party input. Independent boards regulating crucial institutions necessary for democracy, like the election commission and the media board, no longer ensure multiparty representation. The Constitutional Court itself has been packed and weakened because its jurisdiction has been limited. The constitutional reforms have seriously undermined the independence of the ordinary judiciary through changing the appointment and oversight rules of judges.

2. Identity of the political community. An important criterion for a democratic constitution is that everybody living under it can regard it as his or her own. The Fundamental Law breaches this requirement on multiple counts.

a) Its lengthy preamble, entitled National Avowal, defines the subjects of the constitution not as the totality of people living under the Hungarian laws, but as the Hungarian ethnic nation: 'We, the members of the Hungarian Nation ... hereby proclaim the following'. A few paragraphs down, the Hungarian

\footnotetext{
${ }^{126}$ For the 'official' English translation of the Fundamental Law, see: http://www.kormany.hu/download/7/99/30000 /THE\%20FUNDAMENTAL\%20LAW\%20OF\%20HUNGARY.pdf

${ }^{127}$ In its opinion approved at its plenary session of 17-18 June 2011, the Council of Europe's Venice Commission also expressed its concerns related to the document, which was drawn up in a process that excluded the political opposition and professional and other civil organisations. See: http://www.venice.coe.int/docs/2011/CDL-AD(2011)016-E.pdf. Fidesz's counter-argument was that the other Parliamentary parties excluded themselves from the decision-making process with their boycott, with the exception of Jobbik, which voted against the document.

${ }^{128}$ See a more detailed analysis on the lack of checks and balances in M. Bánkuti \& G. Halmai \& K. L. Scheppele,'From Separation of Powers to a Government without Checks: Hungary's Old and New Constitutions', in G. A. Tóth (Ed.), Constitution for a Disunited Nation. On Hungary's 2011 Fundamental Law, CEU Press, 2012.
} 
nation returns as 'our nation torn apart in the storms of the last century'. The Fundamental Law defines it as a community, the binding fabric of which is 'intellectual and spiritual': not political, but cultural. There is no place in this community for the nationalities living within the territory of the Hungarian state. At the same time, there is a place in it for the Hungarians living beyond the borders.

The elevation of the 'single Hungarian nation' to the status of constitutional subject suggests that the scope of the Fundamental Law somehow extends to the whole of historical, pre-WWI Hungary, and certainly to those places where Hungarians are still living today. This suggestion is not without its constitutional consequences: the Fundamental Law makes the right to vote accessible to those members of the 'united Hungarian nation' who live outside the territory of Hungary. It gives a say in who should make up the Hungarian legislature to people who are not subject to the laws of Hungary.

b) It characterises the nation referred to as the subject of the constitution as a Christian community, narrowing even further the range of people who can recognise themselves as belonging to it. 'We recognise the role of Christianity in preserving nationhood', it declares, not only as a statement of historical fact, but also with respect to the present. And it expects everyone who wishes to identify with the constitution to also identify with its opening entreaty: 'God bless the Hungarians'.

c) The preamble of the Fundamental Law also claims that the 'continuity' of Hungarian statehood lasted from the country's beginnings until the German occupation of the country on 19 March 1944, but was then interrupted only to be restored on 2 May 1990, the day of the first session of the freely elected Parliament. Thus, it rejects not only the communist dictatorship, but also the Temporary National Assembly convened at the end of 1944, which split with the fallen regime. It rejects the national assembly election of December 1945.

3. Intervention into the right to privacy. The Fundamental Law breaks with a distinguishing feature of constitutions of rule-of- law states, namely, that they comprise the methods of exercising public authority and the limitations on such authority on the one hand and the guarantees of the enforcement of fundamental rights on the other. Instead of this, the text brings several elements of private life under its regulatory purview in a manner that is not doctrinally neutral, but is based on a Christian-conservative ideology. With this, it prescribes for the members of the community a life model based on the normative preferences that fit in with this ideology in the form of their obligations towards the community. These values, which are not doctrinally neutral, in other words they are nonliberal in the Walkerian sense discussed earlier, and feature as high up as the Fundamental Law's preamble entitled National Avowal:

'We recognise the role of Christianity in preserving nationhood.'

'We hold that individual freedom can only be complete in cooperation with others.' 'We hold that the family and the nation constitute the principal framework of our coexistence, and that our fundamental cohesive values are fidelity, faith and love'.

'Our Fundamental Law ... expresses the nation's will and the form in which we want to live.' In other words, these values are illiberal in the Orbánian sense quoted earlier.

4. Weakening of the protection of fundamental rights. The decline in the level of protection for fundamental rights is significantly influenced not only by the substantive provisions of the Fundamental Law pertaining to fundamental rights, but also by weakening of institutional and procedural guarantees that would otherwise be capable of upholding those rights that remain under the Fundamental Law. The most important of these is a change to the review power of the Constitutional Court, making it far less capable than before of performing its tasks related to the protection of fundamental rights. Added to this is the change in the composition of the Constitutional Court, taking place prior to the entry into force of the Fundamental Law, which further impeded it in fulfilling its function as protector of fundamental rights.

5. Constitutional entrenchment of political preferences. The new Fundamental Law regulates some issues which are to be decided by the governing majority, while it assigns others to laws requiring a 
two-third majority. This makes it possible for the current government enjoying a two-thirds majority support to write in stone its views on economic and social policy. A subsequent government possessing only a simple majority will not be able to alter these even if it receives a clear mandate from the electorate to do so. In addition, the prescriptions of the Fundamental Law render fiscal policy especially rigid since significant shares of state revenues and expenditures are impossible to be modified in the absence of pertaining two-third statutes. This hinders good governance since it makes more difficult for subsequent governments to respond to changes in the economy. This can make efficient crisis management impossible. The very possibility created by the Fundamental Law to regulate such issues of economic and social policies by means of two-third statutes is incompatible with parliamentarism and the principle of the temporal division of powers.

On 11 March 2013, the Hungarian Parliament added the Fourth Amendment to the country's 2011 constitution, re-enacting a number of controversial provisions that had been annulled by the Constitutional Court. The most alarming change concerning the Constitutional Court was the decision to annul all Court decisions prior to when the Fundamental Law entered into force. At one level, this would have made sense, but the Constitutional Court had already worked out a sensible new rule for the constitutional transition by deciding that in those cases where the language of the old and new constitutions was substantially the same, the opinions of the prior Court would still be valid and could still be applied. In cases in which the new constitution was substantially different from the old one, the previous decisions would no longer be used. Constitutional rights are key provisions that are the same in the old and new constitutions - which means that, practically speaking, the Fourth Amendment annuls primarily the cases that defined and protected constitutional rights and harmonised domestic rights protections to comply with European human rights law. With the removal of these fundamental Constitutional Court decisions, the government has undermined legal security with respect to the protection of constitutional rights in Hungary.

\section{Poland}

Poland's 1989 negotiated democratic transition preceded Hungary's, but it followed Hungary's constitutional backsliding after the Law and Justice Party (known as PiS), led by Jarosław Kaczyński, won parliamentary elections in October 2015. The party had already taken over the presidency in May that year. After Solidarity, led by the proletarian leader Lech Wałęsa, won massive electoral support in partially free elections held in June 1989, Poland's last communist president, General Jaruzelski - based on an arrangement known as 'your president, our prime minister' - was forced to appoint Tadeusz Mazowiecki, Wałęsa's former leading adviser, a liberal intellectual nominated by Solidarity, as prime minister. At the end of 1990, Jarosław Kaczyński ran Wałęsa's winning campaign for the presidency and was rewarded with a position as the head of the presidential chancellery, but later accused him of betraying the revolution, and becoming 'the president of the reds.' Kaczyński's conspiracy theory that liberal intellectuals had become allies to former communists led to a final split known as Solidarity's "war at the top." ${ }^{129}$ The alleged conspiracy between other dissidents and the governing Polish United Workers party also determined how Kaczyński viewed the 'roundtable' agreement in 1989, which lead eventually to the end of the communist regime. ${ }^{130}$ The new government parties both in Hungary and Poland rejected ' 1989 ' for the same reasons: namely, absence of radicalism of the democratic transition, and for the alleged liberation of the Communist elites. ${ }^{131}$

As in Hungary in 1994, the fight among erstwhile Solidarity allies brought Poland's former communists back into power: the Democratic Left Alliance, the successor to the Polish United Worker's Party, won parliamentary elections and the presidency in 1993 and 1995 respectively. In contrast to their failed

\footnotetext{
${ }^{129}$ Ch. Davis, 'The Conspiracy Theorists who have taken over Poland', The Guardian, 16 February 2016.

${ }^{130}$ See J. Gross, 'Jaroslaw Kaczynski’s Party is Rewriting the History of Poland', Financial Times, 13 March 2016.

${ }^{131}$ See I. Krastev, 'Walesa, Gorbatchev and Freedom's End', The New York Times, 14 March 2016.
} 
attempt in Hungary in 1995-1996, the Polish post-communists and the liberals successfully negotiated a new liberal democratic constitution, enacted in 1997. Because the new document enshrined the Catholic church's role in public life, illiberal conspiracy theorists charged that it provided additional evidence of a secret liberal-communist alliance. According to the conspiracists, there is no difference between liberal secularism and communist atheism or between liberal democracy and communist authoritarianism. This led in 2001 to the final division of Solidarity into two rival parties: Civic Platform (led by Donald Tusk), and Law and Justice (led by the Kaczyńskis, Jarosław and his twin brother, Lech), the former acknowledging, and the latter denying, the legitimacy of the new constitutional order.

In 2005, Law and Justice defeated Civil Platform, and Tusk won both the parliamentary and the presidential elections. Lech Kaczyński became President of the Republic, while Jarosław became head of the coalition government, which consisted of Law and Justice, the agrarian-populist Self Defense Party and the nationalist-religious League of Polish Families. The new government proposed a decommunization law, which was partly annulled as unconstitutional by the still independent Constitutional Tribunal. The coalition fell apart in 2007, and Civic Platform won the subsequent elections. Donald Tusk replaced Jarosław Kaczyński as Prime Minister, while Lech remained President until he died after his plane crashed in the Katyn forest near Smolensk in Western Russia in April 2010. Although his support had collapsed by the beginning of 2010, and his chances of re-election at the end of the year were widely assumed to be very low, his death fed the theory of a conspiracy between then Poland's Prime Minister Tusk and Russian President Putin willing to kill the Polish President. ${ }^{132}$

Jarosław Kaczyński's Law and Justice Party returned to power with a vengeance, committed to reshaping the entire constitutional system in order to create a 'new and virtuous Fourth Republic.' This meant a systemic and relentless annihilation of all independent powers that could check the will of the ultimate leader. In that respect, his role model is Viktor Orbán. ${ }^{133}$ In 2011, PiS published a long document, authored largely by Kaczyński himself, on the party's and its leader's vision of the state. The main proposition of this paper is very similar to the one that Orbán described in a speech in 2009: a well-ordered Poland should have a 'centre of political direction,' which would enforce the true national interest. This illiberal counter-revolution of both Orbán and Kaczyński is based on a Communist rejection of checks and balances, as well as constitutionally entrenched rights. ${ }^{134}$

Unlike FIDESZ in 2011, PiS lacks the constitution-making or amending two-thirds majority in the Polish parliament. Therefore, it started to act by simply disregarding the liberal democratic Constitution of 1997. The first victim was the Constitutional Tribunal, which already in 2007 had struck down important elements of PiS' legislative agenda, including limits on the privacy of public officials to be lustrated and freedom of speech and assembly. ${ }^{135}$ In Orbán's playbook, which is seemingly followed by Kaczyński, the other major target has been the media, the civil service and the ordinary courts. As opposed to Hungary, for the dismantlement of liberal democratic institutions PiS does not really needed

132 I. Krastev, 'The Plane Crash Conspiracy Theory That Explains Poland', Foreign Policy, 21 December 2015. On 10 April 2016 at an event to commemorate the sixth anniversary of the crash, Jarosław Kaczyński said that "One wanted to kill our memory, as one was afraid of it. Because someone was responsible for the tragedy, at least in moral terms, irrespectively of what were its reasons...Donald Tusk's government was responsible for that." He added: "Forgiveness is necessary, but forgiveness after admitting guilt and administering proper punishment. This is what we need." 'Poland's Kaczyński blames Tusk's government for President's Jet Crash', Business Insider, 11 April 2016. In early October Kaczyński expressed his doubts that the Polish government will support Tusk for his second term in the European Council with the same explanation. See www.ft.com/content/d6a93538-8a36-11e6-8cb7-e7ada1d123b1?ftcamp=crm/email//nbe/BrusselsBrief/product.

133 As early as 2011 Kaczyński announced he wanted to create 'Budapest in Warsaw.' Cf. J-W. Müller, 'The Problem with Poland', The New York Review of Books, February 11, 2016.

${ }^{134}$ Wojciech Sadurski, professor of constitutional law, who was the Kaczyński brothers' fellow student at the University of Warsaw in the 1970s, says that this vision bears a striking resemblance to the writings of Stanislaw Ehrlich, their joint exMarxist professor. See W. Sadurski, ‘What Make Kaczyński Tick?’, I•CONnect, 14 January 2016.

135 About the battle for the Constitutional Tribunal see T.T. Koncewicz, 'Polish Constitutional Drama: Of Courts, Democracy, Constitutional Shenanigans and Constitutional Self-Defense', I•CONnect, December 6, 2015. 
a new constitution because what they have been doing since the fall of 2015 is already a de facto change to the constitution through sub-constitutional laws. Wojciech Sadurski calls this a constitutional coup d'etat. ${ }^{136}$

In October 2015, before the end of the term of the old Parliament, five judges had been nominated by the outgoing Civil Platform government, even though the nine-year terms of two of the judges would have expired only after the parliamentary elections. Andrzej Duda, the new President of the Republic nominated by PiS, refused to swear in the five new judges elected by the old Sejm, despite the fact that the terms of office for three of them had already started to run. In early December, in accordance with a new amendment to the Law on the Constitutional Tribunal, the new Sejm elected five new judges, who were sworn into office by President Duda in an overnight ceremony. As a reaction to these appointments, the Constitutional Tribunal ruled that the election of two judges whose terms had not expired before the dissolution of the previous Sejm in October 2015 was unconstitutional. The Tribunal also ruled that the election of the other three judges was constitutional, and obliged the President to swear them in. Since President Duda refused to do so, the chief judge of the Tribunal did not allow the five newly elected judges to hear cases.

The governing majority also passed an amendment regarding the organisation of the Tribunal, increasing the number of judges required to be in attendance from 9 out of 15 to 13 out of 15 . It also required decisions of the Tribunal to be taken by a two-thirds majority, rather than a simple majority, which was the existing rule prior to the amendment. With the five new judges, as well as the one remaining judge appointed by the PiS when it was last in government from 2005 to 2007, it may no longer be possible for the Tribunal to achieve the necessary two-thirds majority to quash the new laws. The six-member PiS faction, combined with the new quorum and majority rules, will be enough to stymie the court. Furthermore, the Tribunal is bound to handle cases according to the date of receipt, meaning it must hear all the pending cases, most likely regarding laws enacted by previous parliaments, before any new ones adopted by the new Sejm. For the same reason, the amendment also states that no decision about the constitutionality of a law can be made until the law has been in force for six months. Disciplinary proceedings against a judge can also be initiated in the future by the President of the Republic or by the Minister of Justice, which gives power to officials loyal to PiS to institute the dismissal of judges. In early March 2016, the Constitutional Tribunal invalidated all of the pieces of the law restricting its competences. The government immediately announced that it would not publish the ruling because the Court had made its decision in violation of the very law it invalidated. By Polish law, the decision of the Court takes effect as soon as it is published. If the decision is not published, it cannot take effect. As a reaction to the government's (lack of) action, the General Assembly of Poland's Supreme Court judges adopted a resolution stating that the rulings of the Constitutional Tribunal should be respected, in spite of a deadlock with the government. The councils of the cities of Warsaw, Lodz and Poznan have resolved to respect the Constitutional Tribunal's decisions, in spite of the fact that the government is not publishing its rulings. ${ }^{137}$

At the end of 2016, the Polish parliament adopted three new laws that permitted the President of the Republic to name a temporary Constitutional Tribunal President to replace the outgoing head of the court. The new interim President's first action was to allow the three so-called 'anti-judges', unlawfully elected by the PiS majority in the Sejm, to assume their judicial duties suspended by the previous Tribunal President and participate in the meeting to nominate a new President to the head of the state, who two days later appointed the temporary President as the new permanent President of the Tribunal. With this the Constitutional Tribunal has been captured.

\footnotetext{
${ }^{136}$ M. Steinbeis, 'What is Going on in Poland is an Attack against Democracy', Interview with Wojciech Sadurski, http://verfassungsblog.de/what-is-going-on-in-poland-is-an-attack-against-democracy/

${ }^{137} \mathrm{http} / / / w w w . t h e n e w s . p 1 / 1 / 9 / A r t y k u 1 / 250415$,Polands-Supreme-Court-opposes-government-in-constitutional-wrangle
} 
In Orbán's playbook, which is seemingly followed by Kaczyński, the other major target has been the media. At the end of 2015, the PiS government introduced a new law, the so-called 'small media law', amending the former Law on Radio and Television Broadcasting. This amendment enabled the government to appoint and dismiss the heads of the public television and radio. According to the new rules, the presidents and members of the board of both institutions are to be appointed and dismissed by the Minister of Treasury instead of the National Broadcasting Council from among multiple candidates. The law also terminated the previous managers' and board members' contracts with immediate effect, allowing the government to replace them. Since the 'small media law' was about to expire on 30 June 2016, the government in April submitted the 'large media law' to the Sejm. The draft bill planned to turn public broadcasters into 'national media', which is obliged to spread the views of the Polish parliament, government and president, and have to 'respect Christian values and universal ethical principles'. The national media entities are supervised by the newly established National Media Council.

The third danger to PiS' 'centre of political direction' has been an apolitical civil service. Here Kaczyński, just like Orbán, started the complete politicization of the civil service by removing a previously existing rule that the new head of the civil service must be a person who has not been a member of a political party for the last five years. The same law also allows the new head to be appointed from outside the civil service. Another element of Orbán's agenda was to build up a surveillance state. In early February 2016, the new Polish Parliament also passed a controversial surveillance law that grants the government greater access to digital data and broader use of surveillance for law enforcement. On 13 June 2016, the Venice Commission issued an opinion on this, criticising the government for exercising nearly unlimited capacities without adequate independent checks or reasonable limits to the law. ${ }^{138}$

The next target was the ordinary judiciary. In the summer of 2017, the government rushed three new legislative acts through the Polish Parliament: (a) The law on the Supreme Court; (b) the Law on the National Council for the Judiciary; and (c) the Law on the Ordinary Courts' Organisation. The first two laws were vetoed but the third adopted ${ }^{139}$. The latter alone is enough to undermine the independence of Polish courts by permitting the government to replace the leadership of the lower courts.

In early May 2016, Jarosław Kaczyński announced his party's aim to change the 1997 Constitution: 'the constitution must be verified every twenty years', hinting 'next year will be the $20^{\text {th }}$ anniversary of Poland's contemporary basic law'. He admitted however that 'we might not find enough support to change the constitution this term, but it's time to start to work. We can ask Poles if they prefer Poland that we've all seen or the one that's ahead of us'. ${ }^{140}$ A day later Polish President Andrzej Duda said the country's current constitution was a 'constitution of a time of transition', adding that 'it should be examined, a thorough evaluation carried out and a new solution drawn up'. ${ }^{141}$ On 3 May 2017, on the anniversary of the 1791 Polish constitution, President Duda announced that he wanted to hold a referendum in 2018 on the current constitution. His stated reason was that the present Polish people should decide what kind of constitution they wanted, how strong the president and parliament should be, and which rights and freedoms should be emphasized. ${ }^{142}$ These references to a new basic law leave open how the party intends to circumvent the lack of the necessary two-thirds majority in the Sejm for constitution-making. But as critics argue, PiS does not really need a new constitution because what they have been doing since the fall of 2015 is already a de facto change to the constitution through subconstitutional laws.

\footnotetext{
138 http://www.venice.coe.int/webforms/documents/?pdf=CDL-AD(2016)012-e

139 As Wojciech Sadurski argued President Duda's bills tabled to replace the laws vetoed by him are as unconstitotonal as the orginal ones. See W. Sadurski, 'Judicial „Reform” in Poland: The President's Bills are as Unconstitutional as the Ones he Vetoed', Verfassungsblog, 28 November 2017.

$140 \mathrm{http}: / /$ uatoday.tv/news/poland-may-soon-change-its-constitution-j-kaczy-ski-642126.html

${ }^{141} \mathrm{http} / / /$ www.thenews.pl/1/9/Artykul/251184,Polish-president-calls-for-constitution-to-be-reexamined

$142 \mathrm{http}: / /$ foreignpolicy.com/2017/05/03/on-anniversary-of-first-constitution-polish-president-calls-for-referendum/
} 


\section{Conclusion}

In the first part of this paper, I tried to answer the question, whether there is a genuine constitutional theory of 'illiberal constitutionalism'? I argued that the constitutional concept, which rejects liberalism as a constitutive precondition of democracy, cannot be in compliance with the traditional idea of liberal democratic constitutionalism. This concept has nothing to do with any majoritarian constitutional model based on the separation of power, or with political constitutionalism, or any kind of weak judicial review, and it misuses the concept of constitutional identity.

The second part of the paper investigated the social, economic and political relations of illiberal societies. Regarding the first I found that there has been a very weak historical tradition of liberalism and modernization in the East-Central European societies, and also the main driving force of the transition to liberal democracy was to reach the living standard of the West. The lack of success to achieve this goal, together with the accumulation of wealth by some former members of the Communist nomenclature, and the failures of redistributive justice efforts were the reasons of disappointment also in the liberal democratic pursuits. Regarding the economic relations the rise of economic inequality and the decline of social security and solidarity has paradoxically partly been caused by the neoliberal economic policy of some of the illiberal political forces. These political actors have changed the entire political and constitutional structure into a illiberal system mostly not based on their ideological conviction, but rather for the sake of building up and keeping an unrestrained power.

One of the reasons of the illiberal turn has been that there was a lack of consensus about liberal democratic values at the time of the transition. In the beginning of the democratic transitions in these new democracies, preference was given to general economic effectiveness over mass civic and political engagement. ${ }^{143}$ The satisfaction of basic economic needs was so important for both ordinary people and the new political elites that constitutions did not really make a difference. ${ }^{144}$ Between 1989 and 2004, all political forces accepted a certain minimalistic version of a 'liberal consensus', understood as a set of rules and laws rather than values, according to which NATO and EU accession were the main political goals. But as soon as the main political goals were achieved, the liberal consensus died, ${ }^{145}$ and full democratic consolidation was never achieved. ${ }^{146}$

An initial failure of the 1989 constitutional changes - namely the disproportional election systems - also contributed to the electoral victories of Fidesz in Hungary and PiS in Poland, the illiberal autocratic forces. In the case of Fidesz 53 percent vote share into 68 percent in 2010 and 45.5 percent into 67 percent of the seats in Parliament in 2014. This made Fidesz able to change the entire constitutional system after its electoral success in 2010. PiS in 2015 got 51 percent of the seats in the Sejm for 37.6 percent of the votes. With their absolute majority they were able to enact laws- after packing the Constitutional Tribunal even unconstitutional ones - without any need to consult with their parliamentary opposition.

According to some authors, the prospects for liberal constitutional democracy in the newly independent states of Central and Eastern Europe following the 1989-90 transition were diminished by a technocratic, judicial control of politics, which blunted the development of civic constitutionalism, civil society, and participatory democratic government as necessary counterpoints to the technocratic

\footnotetext{
${ }^{143}$ Dorothee Bohle and Béla Greskovits state that East Central European democracies had a 'hollow core' at their inception. See D. Bohle and B. Greskokovits, Capitalist Diversity on Europe's Periphery, Cornell University Press, 2012.

144 See Preuss 1993, 3.

${ }^{145}$ See I. Krastev, 'Is East-Central Europe Backsliding? The Strange Death of the Liberal Consensus', 18. Journal of Democracy, (October 2007), 56-63.

146 J. Dawson and S. Hanley, 'What's Wrong with East-Central Europe? The Fading Mirage of the Liberal Consensus',7 Journal of Democracy, (January 2016), 20-34.
} 
machinery of legal constitutionalism. ${ }^{147}$ Adherents to this viewpoint argue that the legalistic form of constitutionalism (or legal constitutionalism), while consistent with the purpose of creating the structure of the state and setting boundaries between the state and citizens, jeopardised the development of participatory democracy. ${ }^{148}$ In other words, legal constitutionalism fell short, reducing the Constitution to an elite instrument, especially in countries with weak civil societies and weak political party systems that undermine a robust constitutional democracy based on the idea of civic self-government. ${ }^{149}$

One can raise the hypothetical question whether earlier and more inclusive or participatory constitutionmaking processes could have ensured the durability of democratic institutions. Indeed, there was no early constitution making, and the amendment processes that happened instead were not participatory. Neither Poland nor Hungary enacted a new constitution right after the democratic transitions of 1989. Instead, in both countries as a result of the Round Table negotiations, between the representatives of the authoritarian Communist regime and their democratic opposition, the illegitimate legislature was put in the position of enacting modifications to the old Stalinist constitutions. This was done based on the elite agreement without any consultation with the people. In the case of Poland, the 1952 Constitution was slightly modified in April 1989, while in Hungary the 1949 Constitution was comprehensively amended in October 1989. This was called by Andrew Arato 'post-sovereign' constitution-making. ${ }^{150}$ It is true that in Poland, the democratically elected Parliament enacted the so called Small Constitution in 1992, but it only changed some elements of the state organization, without the ambition of becoming the final closing act of the democratic transition. The new constitution was only enacted in 1997, again without participatory process, like a referendum. In Hungary, a similar new constitution-making effort failed in 1996, and even though the content of the 1989 comprehensive amendment fulfilled the requirements of a liberal democratic constitution, but its heading had 1949 in it. With that Fidesz after its electoral victory in 2010 could claim the need to enact a new constitution of the democratic transition and it had all the votes to enact what it was wishing to. But this wasn't a liberal democratic constitution anymore.

One can only speculate, whether an earlier and more participatory constitution-making would have been a guarantee against backsliding. There is nothing to suggest that an earlier and more participatory constitution-making process would have prevented the populist turn. As the Polish example proves even the existence of a liberal democratic constitution does not constitute an obstacle against backlash. In my view, those proponents of participatory constitutionalism who argue that with participation backsliding would not necessarily have happened, do not sufficiently take into account the rise of populism and the lack of civic interest in constitutional matters, due to poor constitutional culture. ${ }^{151}$

So far the liberal elite seems to be unable to protect the liberal democratic ideals, which certainly indicates that the special historical circumstances require a longer period of time the build up a liberal democratic political and constitutional culture. But the democratic backsliding is not a proof of the failure of liberal democracy altogether, as illiberal leaders and their court ideologists want people to believe.

${ }^{147}$ See this argument in P. Blokker, New Democracies in Crises? A Comparative Constitutional Study of the Czech Republic, Hungary, Poland, Romania and Slovakia, Routledge, 2013. Also Wojciech Sadurski argued that legal constitutionalism might have a 'negative effect' in new democracies and might lead to the perpetuation of the problem of both weak political parties and civil society. See W. Sadurski, 'Transitional Constitutionalism: Simplistic and Fancy Theories', in A. Czarnota, M. Krygier \& W. Sadurski (Eds.), Rethinking the Rule of Law After Communism, CEU Press, Budapest, 2005, pp. 9-24.

${ }^{148}$ See R. Albert, 'Counterconstitutionalism', Dalhousie Law Journal, Vol. 31, No. 1, 2008, p. 4.

149 Cf. Sadurski, 2005, p. 23.

${ }^{150}$ A. Arato, 'Post-Sovereign Constitution-Making in Hungary: After Success, Partial Failure, and Now What?', South African Journal of Human Rights, Vol. 26, 2010.

${ }^{151}$ See similarly the crtitical reviews on Blokker's book (Fn. 140) by Jiri Priban and Bogusia Puchalska in ICONnect. Book Review/Response: Paul Blokker, Jiri Priban and Bogusia Puchalska on Civic Constitutionalism, Int'1 J. Const. L. Blog (10 September 2013). 

